\title{
EFFECTS OF CLIMATE, RELIEF, AND VEGETATION ON ANIMALS
}

\author{
Kunakh O. M., Zhukov O. V.
}

\section{INTRODUCTION}

O.L. Belgard's doctrine of ecomorphs, which emerged long before S.W. Meyen's ideas on diatropics (the science of diversity), can be regarded as fully diatropic. O.L. Belgard ${ }^{1}$ pointed out that the basis for the analysis of the ecological structure of communities of living organisms is a life form ${ }^{2}$. The same position is held by K.V. Arnoldi, L.V. Arnoldi ${ }^{3}$, Y.I. Chernov ${ }^{4}$, and S.N. Kirpotin ${ }^{5}$, who consider ecomorphs as the basic elements of the structural organization of ecosystems. The analysis of ecological structure is understood by O.L. Belgard ${ }^{6}$ as revealing the relationships between living organisms and the environment, as well as identifying the degree of adaptation of individual parts of the community to the most important elements of the biogeocenosis. The adaptations of species to the biocenosis as a whole and to each of the structural elements of the ecotope separately (climatope, heliotope, thermotope, etc.) are called ecomorphs ${ }^{7}$. The diversity of biomorphs (ecomorphs), or life forms, is an important

${ }^{1}$ Бельгард А.Л. Лесная растительность Юго-Востока УССР. Киев : Изд-во Киевского государственного университета им. Т.Г. Шевченко, 1950. 263, [1] с.

2 Бельгард А.Л. Лесная растительность Юго-Востока УССР. Киев : Изд-во Киевского государственного университета им. Т.Г. Шевченко, 1950. 263, [1] с.

3 Арнольди К.В., Арнольди Л.В. О биоценозе как одном из основных понятий экологии, его структуре и объеме. Зоологический журнал. 1963. № 42/2. С. 161-183.

4 Чернов Ю.И. Природная зональность и животный мир суши. Москва : Мысль, 1975. 222 с.

${ }^{5}$ Кирпотин С.Н. Жизненные формы организмов как паттерны организации и пространственные экологические факторы. Журнал общей биологии. 2005. № 66/3. С. 239-250.

${ }^{6}$ Бельгард А.Л. Лесная растительность Юго-Востока УССР. Киев : Изд-во Киевского государственного университета им. Т.Г. Шевченко, 1950. 263, [1] с.

${ }^{7}$ Бельгард А.Л. Лесная растительность Юго-Востока УССР. Киев : Изд-во Киевского государственного университета им. Т.Г. Шевченко, 1950. 263, [1] с. 
component of biological diversity ${ }^{8}$. According to D.N. Kashkarov ${ }^{9}$, Y.G. Aleev ${ }^{10}$ and I.Y. Pavlinov ${ }^{11}$, ecomorphs equally display both intrinsic (physiological, morphological, etc.) and "external" (connections with the environment) specificity of organisms. According to O.L. Belgard ${ }^{12}$, ecomorphs are distinct from life forms, as the latter are commonly understood as adaptations that are reflected in the external appearance of a living organism. The life forms, as it is known, are not always associated with changes in morpho-anatomical structure, which primarily concerns plant adaptations to soil fertility and thermal conditions. The use of morphological or physiological traits of animals to assess the degree of species differences is applicable for homogeneous taxonomic or ecological groups with comparable characteristics that can also be interpreted ecologically ${ }^{13}$. Soil macrofauna is represented by a high taxonomic and ecological diversity of forms that are very difficult to compare by morphological or physiological criteria ${ }^{14}$. The ecological content of the characteristics in different groups will not be the same, and

8 Pavlinov I. Comments on biomorphics (ecomorphological) systematics. Zhurnal obshchei biologii, 2010. 71/2, 187-192.

${ }^{9}$ Кашкаров Д.Н. Основы экологии животных. Москва : Медгиз, 1938. 599 с.

${ }^{10}$ Алеев Ю.Г. Экоморфология. Киев : Наукова думка, 1986. 424 с.

11 Pavlinov I. Comments on biomorphics (ecomorphological) systematics. Zhurnal obshchei biologii, 2010. 71/2, 187-192.

12 Бельгард А.Л. Лесная растительность Юго-Востока УССР. Киев : Изд-во Киевского государственного университета им. Т.Г. Шевченко, 1950. 263, [1] с.

${ }^{13}$ Zhukov A.V., Kunah O.N., Prokopenko E.V., and Konovalova T.M., 'The pedoturbation activity of the mole rats (Spalax microphthalmus) as a factor og the spatial organization of the spider (Aranei)', News of Dnipropetrovsk State Agrarian and Economic University, 6 (2011), 28-35; Andrusevich K.V., Zhukov A.V., and Kunah O.N., 'Ecomorphic organisation of the mesopedobionts community as the basis of the anthropogenic soils zoological diagnostic', The Journal of V.N. Karazin Kharkiv National University. Biology, 1126/22 (2014), 89-97; Zhukov O., Kunah O., Dubinina Y., and Novikova V., "The role of edaphic and vegetation factors in structuring beta diversity of the soil macrofauna community of the Dnipro river arena terrace', Ekológia (Bratislava), 37/3 (2018), 301-327.

${ }^{14}$ Findik Ö., 'Spatial and seasonal distribution of macroinvertebrates in high altitude reservoir (Beyler Reservoir, Turkey)', Chinese Journal of Oceanology and Limnology, 31/5 (2013), 994-1001; Gongalsky K.B., Belorustseva S.A., Kuznetsova D.M., Matyukhin A.V., Pelgunova L.A., Savin F.A., and Shapovalov A.S., 'Spatial avoidance of patches of polluted chernozem soils by soil invertebrates', Insect Science, 16/1 (2009), 99-105; Maslikova K.P. and Zhukov O.V., 'Біологічне різноманіття та екосистемні сервіси техноземів, створених на територіях видобутку корисних копалин', Agrology, $2 / 4$ (2019), 247-57. 
the basis for their comparison will be unequal. Therefore, we apply the ecomorphic analysis of soil animals to describe the ecological characteristics $^{15}$. In this connection, the merons are ecomorphs, and the regular series of transformation of ecomorphs are refrences. For example, a cenomorph is a meron, while stepants, sylvants, pratants, and paludants constitute a refrain. Similarly, trophomorphs, hygromorphs, and heliomorphs decompose into a refrain. The diatropic network, to which the system of plant ecomorphs belongs, is the basis for extending this system to animals as well. The holistic and regular character of the variability of living organisms within the diatropic network in the context of ecomorphs is reflected in the concept of ecomorphic matrices. Thus, the formal procedure of extending the system of plant ecomorphs to soil animals has as its theoretical justification the representation of the diatropic network as well. However, this operation can be regarded as a hypothesis that requires experimental confirmation.

\section{Spatial hierarchy of the ecological niche}

A.D. Pokarzewski et al. ${ }^{16}$ consider the organization of soil animal communities at the levels of the study site, biogeocenosis, landscape, and regional level. The membership of a species to a particular ecological group, or ecomorph, can be identified on the basis of the landscapeecological distribution of species in the ecological space. The different approaches to the identification of ecomorphs at the landscape level are conventionally considered independent and form an ecological matrix (in multidimensional space, a multidimensional matrix, or tensor) ${ }^{17}$. At the biogeocenosis level, the degree of correlation between ecomorphs is likely to be higher, so soil animals will form local, but functionally significant, assemblages. The regular correlation of ecomorphs in these functional groups will be a reflection of their organizational structure and ecological diversity. The data obtained indicate the validity of the

15 Жуков О.В. Екоморфічний аналіз консорцій грунтових тварин. Дніпропетровськ : Вид-во «Свідлер А. Л.», 2009. 239 с.

16 Покаржевский А.Д., Гонгальский К.Б., Зайцев А.С., Савин Ф.А. Пространственная экология почвенных животных. Товарищество научных изданий КМК, 2007.

${ }^{17}$ Bookstein F.L., 'Tensor biometrics for changes in cranial shape', Annals of Human Biology, 11/5 (1984), 413-37; Principal T., Analysis T., Leibovici A.D., Leibovici M.D., Gpl L., Date R.C., and Cos C., 'Package "PTAk", (2012). 
suggested assumption ${ }^{18}$. It is important to note the fact that the functional groups identified in the ecological space by RLQ-analysis show regular patterns of spatial variability. The local functional groups have ecological characteristics that reveal, in terms of some ecomorphs, the properties of others occupying a higher hierarchical position. Thus, it was found that within the studied area, steppe ecomorphs are represented by megatrophs, xerophiles, megatrophocenomorphs, and mostly by phytophagous or predatory forms. Meadow and marsh forms are predominantly understory (marsh) or burrowing (meadow), hygrophiles or ultra-hygrophiles, ultra-megatrophocoenomorphs, and saprophages ${ }^{19}$. The pioneer complex of destructive loci is represented by a functional group that does not have a clear cenotic status, but tends to be of the steppe type. This result brings us closer to understanding the mechanisms of transformation of the soil animal community under anthropogenic impact. For this purpose, we should return to the understanding of cenomorphs as indicators of the types of the substance cycle and energy flow according to O.L. Belgard. In such an interpretation, we observe the destruction of the systemic cenotic unity of the complex under anthropogenic influence, and the functional group appears to us as a situational set of species. Obviously, such an interpretation is hypothetical and requires further verification. However, the considered algorithm of material collection and statistical processing provides a practical tool for solving this problem.

\section{A life form}

As D.A. Krivolutsky ${ }^{20}$ pointed out, a life form is first of all a biological indicator of certain natural conditions. According to the set of life forms represented in a certain territory, it is possible to judge quite

18 Kunah O.N., 'Functional and spatial structure of the urbotechnozem mesopedobiont community', Visnyk of Dnipropetrovsk University. Biology, ecology, 24/2 (2016), 473-83; Zhukov A.V., Kunah O.N., Novikova V.A., and Ganzha D.S., 'Phytoindication estimation of soil mesopedobionts communities catena and their ecomorphic organization', Biological Bulletin of Bogdan Chmelnitskiy Melitopol State Pedagogical University, 6/3 (2016), 91-117.

${ }^{19}$ Zhukov O., Kunah O., Dubinina Y., and Novikova V., 'The role of edaphic, vegetational and spatial factors in structuring soil animal communities in a floodplain forest of the Dnipro river', Folia Oecologica, 45 (2018), 8-23; Kunah O., 'Functional and spatial structure of the urbotechnozem mesopedobiont community'.

20 Криволуцкий Д.А. Жизненные формы и биологическое разнообразие животных. Бюлютень Московского общества испытателей природы. Отд. Биол.. 1999. № 104/5. С. 61-67. 
correctly about the degree of habitat diversity. In his extensive work "Ecomorphology", Yu.G. Aleev ${ }^{21}$ notes that in relation to animals, the term and concept of life form was first used by botanist H. Gams ${ }^{22}$. He proposed a system of the life forms, which encompassed both plants and animals. However, his research was botanically oriented and did not attract sufficient attention of zoologists. A significant contribution to the development of the idea of animal life forms was made by K. Friederichs ${ }^{23}$ and D.N. Kashkarov ${ }^{24}$. According to K. Friederichs ${ }^{25}$, the same life form includes those living creatures (species, generations or stages of development) that live in similar habitats and lead a similar way of life. D.N. Kashkarov ${ }^{26}$ defined the life form as follows: "The type of animal that is in perfect harmony with the ambient conditions, we call the life form, taking this term from botanists. The "life form" reflects, as in a mirror, the most important, dominant features of the habitat. One can distinguish, for example, the type of diver, the type of shrew, the type of arboreal climbing animal, etc.". D.N. Kashkarov ${ }^{27}$ believed that when identifying ecological types or "life forms" it is necessary to base not on constitutive, phylogenetic features, but on adaptive features, between which and environmental factors there is a certain dependence, harmony.

In 1948, M.P. Akimov published his work "Biocenotic working system of life forms - biomorph",28, in which he outlined his ideas about the structure of biocenosis and about the biomorphic approach for analyzing the structure of animal population. He defines a biomorph as follows: "In the aspect of biocenosis, each plant or animal species included in its composition should be considered as a certain life form, understanding by this term this or that type of adaptation of the organism to the main factors of its habitat. When identifying biomorphs, it is important to characterize the organism in terms of its relation to abiotic

${ }^{21}$ Алеев Ю.Г. Экоморфология. Киев : Наукова думка, 1986. 424 с.

22 Gams H. 'Prinzipienenfragen der Vegetationsforschung. Ein Beitrag zur Bergiffsklarung und Methodik der Biocoenologie', Vierteljahrsschr. Naturf. Ges. Zurich., 63 (1918), 293-493.

23 Friederichs K., Die Grundfragen und Gesetzmassigkeiten der land- und forstwirschaftlichen Zoologie, insbesondere der Entomologie, Parey, 1930.

${ }^{24}$ Кашкаров Д.Н. Основы экологии животных. Москва : Медгиз, 1938. 599 с.

25 Friederichs, Die Grundfragen und Gesetzmassigkeiten der land- und forstwirschaftichen Zoologie, insbesondere der Entomologie.

${ }^{26}$ Кашкаров, Основы экологии животных.

${ }^{27}$ Кашкаров, Основы экологии животных.

28 Акимов М.П. Биоценотическая рабочая схема жизненных форм биоморф. Науч. зап. Днепропетр. госун-та. 1948. С. 61-64. 
and biotic factors of the environment, as well as in terms of its place and role in the biocenosis. An application of the system of biomorphs makes it possible to briefly characterize each animal species in terms of its main characteristic habitat and form of movement, food composition and method of its harvesting and, finally, in terms of its body size, which largely determine the place occupied by the species in the food chains and cycle. The system of animal biomorphs includes topomorphs, chemomorphs (for hydrobionts), climomorphs (for aerobionts), and trophomorphs" 29 .

The membership in ecological groups of animals has a conditional character and is determined by the spatial range within which the corresponding ecological classification is established and by the scale level, which determines the degree of detail of the classification system. The ecomorphs of plants and animals as an ecological classification are also a context-dependent generalization of information about their relationship with the environment. The landscape-biogeocenotic level is basic when considering ecological phenomena in the tradition of steppe forest science ${ }^{30}$. It is this circumstance that determines the large-scale level of plant and animal ecomorphs. The proportion of different ecomorphs in a community characterizes its ecomorphic structure. Ecomorphs are in certain relationships with each other, which creates the ecomorphic organization of the community. The ecomorphic matrices are a form of representation of the ecomorphic organization ${ }^{31}$.

\section{Ecological gradients}

For a forest community in the steppe zone, the main external ordinates that determine the ecomorphic organization are the regime of moisture and mineralization of the edaphotope ${ }^{32}$. These ordinates are

29 Акимов М.П. Биоценотическая рабочая схема жизненных форм биоморф. Науч. зап. Днепропетр. госун-та. 1948. С. 61-64.

30 Бельгард А.Л. Степное лесоведение: Москва : Лесная промышленность, 1971. $336 \mathrm{c}$.

${ }^{31}$ Zhukov A.V. 'Интерпретация ценоморф растений юго-востока Украины в терминах фитоиндикационных шкал', Acta Biologica Sibirica, 4/4 (2018), 57-70; Zhukov A.V., Kunah O.N., Novikova V.A., and Ganzha D.S., 'Фитоиндикационное оценивание катены сообществ почвенной мезофауны и их экоморфическая организация', Biological Bulletin of Bogdan Chmelnitskiy Melitopol State Pedagogical University, 6/3 (2016), 91-117.

32 Бельгард А.Л. Степное лесоведение: Москва : Лесная промышленность, 1971. $336 \mathrm{c}$. 
taken as independent and form the typological system of forests of the steppe zone. In reality, the independence (orthogonality) of the ordinates is not fulfilled, but at the landscape level, this circumstance can be neglected. The orthogonality means that each gradation of trophicity should correspond to all possible gradations of moisture or vice versa. If this is not the case (and not all cells of Belgard's typology are filled), then there is a mutual dependence, or correlation, between trophicity and humidity, and the typological system (as an ecological matrix) is oblique. The ecomorphic matrix is not a two-dimensional object, but a multidimensional one, so it is more correct to call it a hypermatrix or a tensor. Thus, the ecomorphic tensor reflects the complex nature of interaction of living organisms with the environment. This tensor is not orthogonal, since there is always a correlation between the ordinates, and the correlation structure is a characteristic index that reflects the level of ecomorphic organization of a particular community. For soil animals, the following ecomorphs can be distinguished: cenomorphs, trophomorphs, trophocenomorphs, topomorphs, and hygromorphs ${ }^{33}$. Under the conditions of a particular community, the variability of the ecomorphic structure is associated with the coordinated variability of certain ecomorphs. The correlation compositions of ecomorphs reveal the nature of the mechanisms of community adaptation to the dynamics of environmental factors.

An assessment of habitat properties is essential for predicting the impact of perturbations on living communities and for identifying environmental properties that are important for protecting diversity and maintaining ecosystem functions ${ }^{34}$. The differences in the composition of species in a community and the variability in response to environmental conditions are a key constraint to developing a habitat model that could be applied to different species in different ecosystems ${ }^{35}$. A functional classification of animals, in which species characterized by common ecological features are grouped together, provides an alternative to

33 Zhukov A.V. and Shatalin D.B., 'Гигротоп и трофотоп биогеоценозов степного приднепровья как детерминанты $\beta$-разнообразия сообществ дождевых червей (Lumbricidae)', Biological Bulletin of Bogdan Chmelnitskiy Melitopol State Pedagogical University, 2016. 6/2. C. 188-222.

${ }^{34}$ Brind'Amour A., Daniel B., Dray S., and Legendre P., 'Relationships between species feeding traits and environmental conditions in fish communities: A threematrix approach', Ecological Applications, 21/2 (2011), 363-77.

35 Olden J.D. and Jackson D.A., (2002) 'A comparison of statistical approaches for modelling fish species distributions', Freshwater Biology, 47/10 , P. 1976-95. 
individual species-environment models and may avoid this barrier ${ }^{36}$. The groups of species that share ecological properties form operational units that respond to environmental factors more predictably than individual species, greatly increasing the predictive abilities of a habitat model compared to models created for high levels of taxonomic resolution, such as species ${ }^{37}$. The association of species according to their ecological traits is also a way to identify functional groups of species to assess key ecosystem functions, a crucial step for elucidating functional diversity within and across ecosystems ${ }^{38}$. The habitat filtering hypothesis suggests that species with similar ecological needs form functional groups that occupy similar habitats ${ }^{39}$. Combining species by traits such as morphology or behavior is one way to simplify the study of speciesdiverse communities ${ }^{40}$.

${ }^{36}$ Dornelas M., Magurran A.E., Buckland S.T., Chao A., and others 'Quantifying temporal change in biodiversity: challenges and opportunities', Proceedings of the Royal Society B: Biological Sciences, 280/1750 (2013), 20121931; Davies T.J., Regetz J., Wolkovich E.M., and McGill B.J., 'Phylogenetically weighted regression: A method for modelling non-stationarity on evolutionary trees', Global Ecology and Biogeography, 28/2 (2019), 275-85; McGill B.J., Etienne R.S., Gray J.S., Alonso D., and others 'Species abundance distributions: Moving beyond single prediction theories to integration within an ecological framework', Ecology Letters, 10/10 (2007), 995-1015; McGill B.J., Enquist B.J., Weiher E., and Westoby M., 'Rebuilding community ecology from functional traits', Trends in Ecology and Evolution, 21/4 (2006), 178-85.

${ }^{37}$ Austen D.J., Bayley P.B., and Menzel B.W., 'Importance of the Guild Concept to Fisheries Research and Management', Fisheries, 19/6 (1994), 12-20.

${ }^{38}$ Hardy O.J. and Jost L., 'Interpreting and estimating measures of community phylogenetic structuring', Journal of Ecology, 96/5 (2008), 849-52; Mouillot D., Spatharis S., Reizopoulou S., Laugier T., Sabetta L., Basset A., and T. Do Chi, 'Alternatives to taxonomic-based approaches to assess changes in transitional water communities', Aquatic Conservation: Marine and Freshwater Ecosystems, 16/5 (2006), 469-82; Brind'Amour A., Mahévas S., Legendre P., andBellanger L., 'Application of Moran Eigenvector Maps (MEM) to irregular sampling designs', Spatial Statistics, 26 (2018), 56-68.

${ }^{39}$ Lososová Z., Šmarda P., Chytrý M., Purschke O., and others 'Phylogenetic structure of plant species pools reflects habitat age on the geological time scale', Journal of Vegetation Science, 26/6 (2015), 1080-89; Billeter R., Liira J., Bailey D., Bugter R., and others, 'Indicators for biodiversity in agricultural landscapes: A panEuropean study', Journal of Applied Ecology, 45/1 (2008), 141-50; Zobel M., 'The relative role of species pools in determining plant species richness: An alternative explanation of species coexistence?', (1997).

40 Angermeier P.L. and Winston M.R., 'Local vs. Regional Influences on Local Diversity in Stream Fish Communities of Virginia', Ecology, 79/3 (1998), 911. 


\section{Methods}

Soil fauna of urban ecosystems is a traditional object of study in soil zoology and urban ecology ${ }^{41}$. Specific of the urban soils, which differ from zonal ones by a set of morphological, physico-chemical and biological properties, are formed in urban conditions ${ }^{42}$. In the conditions of large industrial cities, the main components of anthropogenic load are the complex effect of urbanization and recreation ${ }^{43}$. Spatial heterogeneity increases in anthropogenic soils in general ${ }^{44}$. The nature of the influence of this process on the spatial patterns of soil mesofauna of urban soils was not investigated.

\section{Ecological ordination}

The relationship between species traits and environmental properties is usually assessed indirectly using a two-step analysis. First, species

${ }^{41}$ Vergnes A., Blouin M., Muratet A., Lerch T.Z., and others 'Initial conditions during Technosol implementation shape earthworms and ants diversity', Landscape and Urban Planning, 159 (2017), 32-41; Tóth Z., Szlavecz K., Epp Schmidt D.J., Hornung E., and others. 'Earthworm assemblages in urban habitats across biogeographical regions', Applied Soil Ecology, 151 (2020); Roithmeier O. and Pieper S., 'Influence of Enchytraeidae (Enchytraeus albidus) and compaction on nutrient mobilization in an urban soil', Pedobiologia, 53/1 (2009), 29-40; Tóth Z. and Hornung E., 'Taxonomic and functional response of Millipedes (Diplopoda) to urban soil disturbance in a metropolitan area', Insects, 11/1 (2019), 25.

42 Martynenko I.A., Meshalkina J.L., Rappoport A.V., and Shabarova T.V., 'Spatial heterogeneity of some soil properties of the botanical garden of Lomonosov Moscow State University', Springer Geography, (Springer, 2019), pp. 185-94; Gan H. and Wickings K., 'Soil ecological responses to pest management in golf turf vary with management intensity, pesticide identity, and application program', Agriculture, Ecosystems and Environment, 246 (2017), 66-77; Goncharova O.Y., Matyshak G.V., Udovenko M.M., Bobrik A.A., and Semenyuk O.V., 'Seasonal and annual variations in soil respiration of the artificial landscapes (Moscow Botanical Garden)', Springer Geography, (Springer, 2019), pp. 112-22.

${ }^{43}$ Smorkalov I.A. and Vorobeichik E.L., 'The impact of a large industrial city on the soil respiration in forest ecosystems', Eurasian Soil Science, 48/1 (2015), 106-14; Vorobeichik E.L., 'Populations of earthworms (Lumbricidae) in forests of the middle urals in conditions of pollution by discharge from copper works', Russian Journal of Ecology, 29/2 (1998), 85-91; Vorobeichik E.L, Ermakov A.I., Zolotarev M.P., and Tuneva T.K., 'Changes in diversity of soil macrofauna in industrial pollution gradient', Rej, 21/1 (2012), 203-18.

${ }^{44}$ Medvedev V.V., 'Soil penetration resistance and penetrographs in studies of tillage technologies', Eurasian Soil Science, 2009. 42/3, 299-309; Демидов А.А., Кобец А.С., Грицан Ю.И., Жуков А.В. Пространственная агроэкология и рекультивация земель, («Свидлер А.Л.», 2013). 
abundance is associated with environmental conditions, and species response to variability in environmental properties is then correlated with biological or physiological traits of species ${ }^{45}$. $R Q L$ analysis correlates ecological features of species with environmental conditions ${ }^{46}$. This analysis examines the joint structure between three data tables: the R-table (contains environmental variables), the $Q$-table (contains species features), and the $L$-table (species abundance) ${ }^{47}$. The $L$-table acts as a link between the $R$ and $Q$ tables and measures the intensity of the link between them. Before the analysis proper, three separate analyses are performed. A correspondence analysis is applied to the $L$-table, resulting in an optimal correlation structure between sites and species abundance weights. Ordination of the $R$ and $Q$ tables is performed using principal component analysis. Thus, $R Q L$ performs a coinertia analysis of the $R, Q$, and $L$ cross-matrices.

This analysis maximizes the covariance between the scores of study sites with respect to environmental properties, as expressed by Table $R$, and the scores of species with respect to their environmental properties, as expressed by table $Q^{48}$. The result can be a better joint combination of ordination of sites by their environmental characteristics, ordination of species by their properties, and simultaneous ordination of

${ }^{45}$ Buisson L., Thuiller W., Lek S., Lim P., and Grenouillet G., 'Climate change hastens the turnover of stream fish assemblages', Global Change Biology, 14/10 (2008), 2232-48; Thuiller W., Lavorel S., Midgley G., S.Lavergne, and Rebelo T., 'Relating plant traits and species distributions along bioclimatic gradients for 88 Leucadendron taxa', Ecology, 85/6 (2004), 1688-99; Santoul F., Cayrou J., Mastrorillo S., and Céréghino R., 'Spatial patterns of the biological traits of freshwater fish communities in south-west France', Journal of Fish Biology, 66/2 (2005), 301-14; Brind'Amour, Daniel, Dray, and Legendre, 'Relationships between species feeding traits and environmental conditions in fish communities: A threematrix approach'.

${ }^{46}$ Dolédec S., Chessel D., Ter Braak C.J.F., and Champely S., 'Matching species traits to environmental variables: A new three-table ordination method', Environmental and Ecological Statistics, 3/2 (1996), 143-66.

${ }^{47}$ Dray S., Said S., and Débias F., 'Spatial ordination of vegetation data using a generalization of Wartenberg's multivariate spatial correlation', Journal of Vegetation Science, 2008. 19/1, 45-56.

${ }^{48}$ Minden V., Andratschke S., Spalke J., Timmermann H., and Kleyer M., 'Plant trait-environment relationships in salt marshes: Deviations from predictions by ecological concepts', Perspectives in Plant Ecology, Evolution and Systematics, 14/3 (2012), 183-92. 
species and sites ${ }^{49}$. RQL analysis combines three separate ordination solutions with maximization of the covariance between species features and environmental properties through coinertia analysis ${ }^{50}$. Further, a hierarchical cluster analysis of species weights along the two RQL axes by Ward's method yields functional groups ${ }^{51}$. The optimal number of groups can be obtained using the Calinski criterion ${ }^{52}$. Clusters show the distribution of species in the species feature space - ecological space.

Among multivariate environmental data processing techniques, Correspondence Analysis (CA $)^{53}$, also known as Reciprocal Averaging $(\mathrm{RA})^{54}$, is a community ordination method for studying the separation of species niches or ecological amplitude of species ${ }^{55}$. The development of this analysis led to the creation of Canonical Correspondence Analysis $(\mathrm{CCA})^{56}$, which is designed to study the differentiation of species niches along environmental gradients. Canonical Correspondence Analysis is most appropriate when the response of species to environmental factors is a unimodal curve ${ }^{57}$. Redundancy analysis (RDA) assumes a linear

49 Buisson, Thuiller, Lek, Lim, and Grenouillet, 'Climate change hastens the turnover of stream fish assemblages'; W. Thuiller, Richardson D.M., Rouget M., Procheş Ş., and Wilson J. R. U., 'Interactions between environment, species traits, and human uses describe patterns of plant invasions', Ecology, 87/7 (2006), 1755-69.

50 Bernhardt-Römermann M., Römermann C., Nuske R., Parth A., Klotz S., Schmidt W., and Stadler J., 'On the identification of the most suitable traits for plant functional trait analyses', Oikos, 117/10 (2008), 1533-41.

${ }^{51}$ Minden V., Andratschke S., Spalke J., Timmermann H., and Kleyer M., 'Plant trait-environment relationships in salt marshes: Deviations from predictions by ecological concepts', Perspectives in Plant Ecology, Evolution and Systematics, 14/3 (2012), 183-92.

${ }^{52}$ Caliñski T. and Harabasz J., 'A Dendrite Method Foe Cluster Analysis', Communications in Statistics, 3/1 (1974), 1-27.

${ }^{53}$ Hill M.O., 'Correspondence Analysis: A Neglected Multivariate Method', Applied Statistics, 23/3 (1974), 340.

${ }^{54}$ Hill M.O., 'Reciprocal Averaging: An Eigenvector Method of Ordination', The Journal of Ecology, 61/1 (1973), 237.

55 Thioulouse J., Simier M., and Chessel D., 'Simultaneous analysis of a sequence of paired ecological tables', Ecology, 85/1 (2004), 272-83; Doledec S., Chessel D., andGimaret-Carpentier C., 'Niche Separation in Community Analysis: A New Method', Ecology, 81/10 (2000), 2914.

56 Ter Braak C.J.F. and Barendregt L.G., 'Weighted averaging of species indicator values: Its efficiency in environmental calibration', Mathematical Biosciences, 78/1 (1986), 57-72.

57 Palmer M.W., 'Putting Things in Even Better Order: The Advantages of Canonical Correspondence Analysis', Ecology, 74/8 (1993), 2215-30. 
response of species to environmental factors ${ }^{58}$. Outlying Mean Index $(\mathrm{OMI})^{59}$ analysis allows for data that reflects both linear and unimodal responses of species to the environment. In the OMI-analysis concept, the ecological niche of a species can be represented as a composition of marginality, tolerance, and residual tolerance. The marginality is a measure of the difference between the habitat conditions of a species and the typical conditions for a given territory and thus indicates the specialization of the species. The tolerance indicates the variability of the species' niche along the axis connecting the center of mass of the ecological conditions of the territory and the center of mass of the sites of the territory where the species is found. This parameter indicates the width of the ecological niche. The variability of the niche in the plane orthogonal to the direction connecting the mass centers of the territory and the species is the residual tolerance.

The spatial distribution of individuals is one of the most important characteristics of individual populations and species as a whole, which is determined by the interaction of many mechanisms - dispersion, reproductive behavior, spatial heterogeneity of habitats, intra- and interspecific competition, anthropogenic pressure ${ }^{60}$. The pattern of spatial organization of population can be considered in the aspect of spatial heterogeneity and spatial structuring ${ }^{61}$. An assessment of spatial heterogeneity is based on the sampling characteristics of the data on the

${ }^{58}$ Doledec, Chessel, and Gimaret-Carpentier, 'Niche Separation in Community Analysis: A New Method'.

59 Thuiller, Lavorel, Midgley, Lavergne, and Rebelo, 'Relating plant traits and species distributions along bioclimatic gradients for 88 Leucadendron taxa'; Doledec, Chessel, and Gimaret-Carpentier, 'Niche Separation in Community Analysis: A New Method'.

60 Boycott, A.E. 'The habitats of land mollusca in Britain', The Journal of Ecology, 22/1 (1934), 1; R. Cameron, 'Differences in the distributions of three species of helicid snail in the limestone district of Derbyshire', Proceedings of the Royal Society of London. Series B. Biological Sciences, 176/1043 (1970), 131-59; Baur A. and Baur B., 'Individual movement patterns of the minute land snail Punctum pygmaeum (Draparnaud) (Pulmonata: Endodontidae)', Veliger, 30 (1988), 372-376; Kramarenko S.S., Kunakh O.N., Zhukov A.V, and Andrusevich E.V., 'Analysis of the spatial distribution patterns of the land snail populations: a geostatistic method approach популяций наземных моллюсков':, February (2016), 5-40.

${ }^{61}$ Huston M., 'A General Hypothesis of Species Diversity', The American Naturalist, 113/1 (1979), 81-101; Pielou E.C., An Introduction to Mathematical Ecology, (Wiley-Interscience, 1969). 
number of individuals within the studied sampling sites. Most often to estimate the measure of spatial heterogeneity the methods of approximation of sampling distribution of number of individuals by Poisson distribution are used, and the ratio of sampling variation to the arithmetic mean $\left(S^{2} / D\right)$ is the basis of calculation of the majority of spatial heterogeneity indices. In case $S^{2} / D$ ratio is close to 1 , the distribution of individuals in the population is close to random, in case $S^{2} / D<1$ is aggregated. Based on this ratio, a number of indices have been constructed that are used to estimate the measure of heterogeneity in the distribution of individuals in space, such as Green's index, Lloyd's "average crowding" index, Ives' index, Moricita index, etc. ${ }^{62}$. The location of the sample sites themselves with respect to each other is not taken into account in any way (it is only important that it is random within the territory occupied by the population). The estimation of spatial structuring can be obtained only if the exact coordinates are marked for each test site. Sample sites can be arranged randomly or in a regular grid. Spatial intrapopulation structuring is reflected in the presence of individual aggregations or their clusters, in mutual arrangement of such aggregations, in their size, distance between their centroids, presence of autocorrelation of numbers of individuals within a studied population ${ }^{63}$. To analyze the spatial intrapopulation structuring, geostatistical methods for different animal groups have been actively used in recent years.

A habitat is characterized by the presence in an area of resources and conditions for a given species that make it possible for that area to be inhabited, including its survival and reproduction ${ }^{64}$. The purpose of studying habitat selection by species is to identify the environmental characteristics that make a place suitable for a species ${ }^{65}$. Neutrality theory neglects differences between individuals in their response to local environmental conditions. In contrast, niche theory indicates that patterns of biodiversity should be directly related to variability in ecological parameters such as physicochemical conditions, disturbance regimes,

${ }^{62}$ Southwood T.R.E. and Henderson P.A., (2000). 'Ecological Methods, 3rd edn'

${ }^{63}$ M.-J. Fortin Dale, M.R.T., ver Hoef, J, (2002) 'Spatial analyses in ecology', Encyclopedia of environmetrics, 4, 2051-58.

64 Chambers R. and Trippel E., 'Early life history and recruitment in fish populations', 1997.

${ }^{65}$ Calenge, C., Dufour A.B, and Maillard D., (2005) 'K-select analysis: A new method to analyse habitat selection in radio-tracking studies', Ecological Modelling, 186/2, 143-53. 
productivity, and competition from other species ${ }^{66}$. Neutrality theory is difficult to test in practice ${ }^{67}$, primarily because key population parameters for multiple species in a community are difficult to measure in the field. Attempts were made to describe species abundance curves from the perspective of neutrality theory or with other models ${ }^{68}$, but differences in the application of approaches are negligible. When well matched, models do not provide information about the underlying biological processes underlying the observed phenomena ${ }^{69}$. Phenomena that would presumably occur in the case of neutral processes have been investigated ${ }^{70}$. One such phenomenon could be "distance attenuation", Since species limitation underlies differences between habitats in a neutral world, one would expect that more distant points of space would be populated by more divergent communities ${ }^{72}$. Differences in local species richness between habitats can be explained by the random

66 Doak D.F., Bigger D., Harding E.K., Marvier M.A., O’Malley R.E., and Thomson D., 'The statistical inevitability of stability-diversity relationships in community ecology', American Naturalist, 151/3 (1998), 264-76; Tokeshi M., 'Resource Utilization, Overlap and Temporal Community Dynamics: A Null Model Analysis of an Epiphytic Chironomid Community', The Journal of Animal Ecology, 55/2 (1986), 491.

${ }^{67}$ Green J.L., Harte J., and Ostling A., 'Species richness, endemism and abundance patterns: Tests of two fractal models in a serpentine grassland', Ecology Letters, 6/10 (2003), 919-28; Shipitalo M.J. and Le Bayon R.C., 'Quantifying the effects of earthworms on soil aggregation and porosity', Earthworm Ecology, Second Edition, (2004), 183-200; Wootton J.T., 'Field parameterization and experimental test of the neutral theory of biodiversity', Nature, 433/7023 (2005), 309-12.

${ }^{68}$ McGill B.J., 'A test of the unified neutral theory of biodiversity', Nature, 422/6934 (2003), 881-85; Volkov I., Banavar J.R., Hubbell S.P., and Maritan A., 'Neutral theory and relative species abundance in ecology', Nature, 424/6952 (2003), 1035-37; Adler P.B. and Lauenroth W.K., 'The power of time: Spatiotemporal scaling of species diversity', Ecology Letters, 6/8 (2003), 749-56.

${ }^{69}$ Thompson R. and Townsend C., 'A truce with neutral theory: Local deterministic factors, species traits and dispersal limitation together determine patterns of diversity in stream invertebrates', Journal of Animal Ecology, 75/2 (2006), 476-84.

70 Shipitalo and Le Bayon, 'Quantifying the effects of earthworms on soil aggregation and porosity'; Wootton, 'Field parameterization and experimental test of the neutral theory of biodiversity'.

${ }^{71}$ Zhou S. and Zhang D., 'Neutral theory in community ecology', Frontiers of Biology in China, 3/1 (2008), 1-8; H. SP, 'The Unified Neutral Theory of Biodiversity and Biogeography'.

72 Green, Harte, and Ostling, 'Species richness, endemism and abundance patterns: Tests of two fractal models in a serpentine grassland'. 
extinction and replacement of species over time. Hubbell ${ }^{73}$ called these processes "ecological drift". The neutrality theory can be tested by comparing the effect of local ecological conditions and the phenomenon of spatial attenuation on the community structure. According to niche theory, the similarity between species-habitat matrices will be positively correlated with the proximity of local ecological conditions. Neutrality theory predicts a negative correlation of species structure with distance between habitats. These differences are often difficult to establish because differences in ecological conditions are often correlated with distance $^{74}$. This approach for testing the neutrality theory can be applied if local conditions and spatial factor are independent ${ }^{75}$.

The ecological niche is a useful model for describing habitat selection by a species. Hutchinson ${ }^{76}$ defines an ecological niche as a hyper-volume in a multidimensional space, defined by environmental variables, where a species can potentially maintain viable populations. Methodologically, the ecological niche can be investigated by general Niche-environment system factor analysis (GNESFA) ${ }^{79}$. Ecological niche factor analysis is based on the assumption that species are not randomly distributed with respect to the ecogeographic variables ${ }^{78}$. The species of interest may be characterized by some marginality (as expressed by the difference in species mean from the global mean of an ecogeographic variable) and some specialization (as manifested by the fact that species variance is less than global variance). GNESFA can be implemented in three versions - FANTER, ENFA and MADIFA. Factor analysis of the ecological niche, taking the environment as the reference (FANTER) considers the deformation of the ecological niche relative to the ecological space which is taken as the reference, i.e. the axes of this space lead to such a condition that the ecological space has a perfect

${ }^{73}$ SP, 'The Unified Neutral Theory of Biodiversity and Biogeography'.

${ }^{74}$ Karst J., Gilbert B., and Lechowicz M. J., (2005) 'Fern community assembly: the roles of chance and the environment at local and intermediate scales', Ecology, 86/9, 2473-86.

75 Townsend C.R. and Hildrew A.G., (1994) 'Species traits in relation to a habitat templet for river systems', Freshwater Biology, 31/3 , 265-75.

76 Hutchinson G.E., (1957) 'Concluding Remarks', Cold Spring Harbor Symposia on Quantitative Biology, 22/0, 415-27.

77 Calenge C. and Basille M., (2008) 'A general framework for the statistical exploration of the ecological niche', Journal of Theoretical Biology, 252/4 , 674-85.

${ }^{78}$ Hirzel, A.H. Hausser J., Chessel D., and Perrin N. (2002), 'Ecological-niche factor analysis: How to compute habitat-suitability maps without absence data?', Ecology, 83/7 , 2027-36. 
spherical shape. On the contrary, the spherical shape is given to the ecological niche in the MADIFA (Mahalanobis distances factor analysis), and the curvature of the ecological space indicates the degree of difference in the properties of the environment from the ecological optimum of the species. The results of MADIFA can be used to construct the most correct map of habitat preference for a given species ${ }^{79}$. A special point of view is possible, in which the two distributions together (ecological niche and ecological space) are treated as focal and referential. This symmetric viewpoint has the advantage outside the choice of the reference distribution. This special case is the basis of the ecological-niche factor analysis (ENFA). In ENFA, the first axis corresponds entirely to marginality, and the subsequent axes describe the specialization of the species. The integration of these axes also makes it possible to construct a map of habitat preference, but unlike MADIFA, this result in ENFA is not mathematically consistent. N. Caruso et al. ${ }^{80}$ note that despite the advantages of GNESFA, this type of analysis is poorly represented in the scientific literature. Even after the publication of the paper ${ }^{81}$, a number of articles continue to use the ENFA approach not only for as a research tool, but also for constructing habitat preference maps ${ }^{82}$. A number of authors use only MADIFA to describe

${ }^{79}$ Caruso N., Guerisoli, M. Luengos Vidal E. M., Castillo D., Casanave E. B., and Lucherini M., 'Modelling the ecological niche of an endangered population of Puma concolor: First application of the GNESFA method to an elusive carnivore', Ecological Modelling, 297 (2015), 11-19; Calenge and Basille, 'A general framework for the statistical exploration of the ecological niche'.

${ }^{80}$ Caruso, Guerisoli, Luengos Vidal, Castillo, Casanave, and Lucherini, 'Modelling the ecological niche of an endangered population of Puma concolor: First application of the GNESFA method to an elusive carnivore'.

${ }^{81}$ Calenge and Basille, 'A general framework for the statistical exploration of the ecological niche'.

${ }^{82}$ C. De Angelo, A. Paviolo, and M. Di Bitetti, 'Differential impact of landscape transformation on pumas ( Puma concolor) and jaguars ( Panthera onca) in the Upper Paraná Atlantic Forest', Diversity and Distributions, 17/3 (2011), 422-36; I. Galparsoro, Á. Borja, J. Bald, P. Liria, and G. Chust, 'Predicting suitable habitat for the European lobster (Homarus gammarus), on the Basque continental shelf (Bay of Biscay), using Ecological-Niche Factor Analysis', Ecological Modelling, 220/4 (2009), 556-67; M. Valle, Á. Borja, G. Chust, I. Galparsoro, and J. M. Garmendia, 'Modelling suitable estuarine habitats for Zostera noltii, using Ecological Niche Factor Analysis and Bathymetric LiDAR', Estuarine, Coastal and Shelf Science, 94/2 (2011), 144-54. 
species distributions ${ }^{83}$. Along with the original work ${ }^{84}$, an article by N. Caruso et al. ${ }^{85}$ to describe the puma ecological niche in southern America using all GNESFA techniques.

\section{Partitioning of spatial variation}

Spatial structure is considered a key concept for explaining processes affecting biotic communities ${ }^{86}$. Space acts either as a factor influencing ecological structure or as a variable that distorts the process of interest ${ }^{87}$. Spatial patterns of communities result from environmental factors, or from biotic interactions ${ }^{88}$. Therefore, to adequately understand ecological communities, it is important to identify spatial patterns and match them to underlying processes ${ }^{89}$. Different ecological processes can manifest themselves at different scales ${ }^{90}$. The diversity of species in a community is related to abiotic environmental factors ${ }^{91}$. This effect is a consequence of the impact of variability in environmental properties on the intensity of

83 Halstead B.J., Wylie, G.D. and Casazza M.L., 'Habitat Suitability and Conservation of the Giant Gartersnake (Thamnophis gigas) in the Sacramento Valley of California', Copeia, 2010/4 (2010), 591-99; L. Hemery, B. Galton-Fenzi, N. Améziane, M. Riddle, S. Rintoul, R. Beaman, A. Post, and M. Eléaume, 'Predicting habitat preferences for Anthometrina adriani (Echinodermata) on the East Antarctic continental shelf', Marine Ecology Progress Series, 441 (2011), 105-16; J.-B. Thiebot, A. Lescroël, D. Pinaud, P. N. Trathan, and C.-A. Bost, 'Larger foraging range but similar habitat selection in non-breeding versus breeding subAntarctic penguins', Antarctic Science, 23/2 (2011), 117-26.

${ }^{84}$ Calenge and Basille, 'A general framework for the statistical exploration of the ecological niche'.

85 Caruso, Guerisoli, Luengos Vidal, Castillo, Casanave, and Lucherini, 'Modelling the ecological niche of an endangered population of Puma concolor: First application of the GNESFA method to an elusive carnivore'.

86 Покаржевский, Гонгальский, Зайцев, and Савин, Пространственная экология почвенных животных.

${ }^{87}$ Stéphane D., 'Moran' $\mathrm{s}$ eigenvectors of spatial weighting matrices in R', 3 (2006), 1-21.

${ }^{88}$ Gendreau-berthiaume B., 'Lab 9 - Spatial analysis : Trend surface analysis and PCNM', Oecologia, (2004), 9.

${ }^{89}$ Legendre P. and Fortin M.J., 'Spatial pattern and ecological analysis', Vegetatio, 80/2 (1989), 107-38.

90 Borcard D. and Legendre P., 'All-scale spatial analysis of ecological data by means of principal coordinates of neighbour matrices', Ecological Modelling, 153/12 (2002), 51-68.

${ }^{91}$ Fischer M.M., 'Quantifying the uncertainty of variance partitioning estimates of ecological datasets', Environmental and Ecological Statistics, 26/4 (2019), 351-66; M. A. Leibold, M. Holyoak, N. Mouquet, P. Amarasekare, J. M. Chase, M. F. Hoopes, R. D. Holt, J. B. Shurin, R. Law, D. Tilman, M. Loreau, and A. Gonzalez, 'The metacommunity concept: A framework for multi-scale community ecology', (2004). 
demographic processes ${ }^{92}$ or competitive interactions ${ }^{93}$. However, using neutral diversity theory, it was shown that many patterns previously thought to result from environmental controls can be caused by constraints on the distribution of ecologically identical species ${ }^{94}$. As a consequence, the notion of differentiated ecological niches of species may not apply to explain many phenomena of communities of living organisms. The niche differentiation processes and neutral processes lead to similar spatial patterns ${ }^{95}$. Dispersal between neighboring sites forms an autocorrelation in neutral communities ${ }^{96}$. In niche-structured communities, community similarity decreases with increasing geographic distance as environmental properties become spatially autocorrelated ${ }^{97}$. Data on communities as truly neutral as niche-structured can be spatially structured because data on communities and environmental factors can be spatially autocorrelated ${ }^{98}$. One method for distinguishing between environmental factor control of community structure and spatial autocorrelation induced by neutral dispersal is fractional ${ }^{99}$. The geographic coordinates are used as predictive variables in direct ordination methods in the form of polynomial terms $(x$,

92 Hutchinson G.E., 'Ecological Aspects of Succession in Natural Populations', The American Naturalist, 75/760 (1941), 406-18; H. G. Gauch, G. B. Chase, and R. H. Whittaker, 'Ordination of Vegetation Samples by Gaussian Species Distributions', Ecology, 55/6 (1974), 1382-90.

93 Chesson P., 'General theory of competitive coexistence in spatially-varying environments', Theoretical Population Biology, 58/3 (2000), 211-37; Smith T.W.and Lundholm J.T., 'Variation partitioning as a tool to distinguish between niche and neutral processes', Ecography, 33/4 (2010), 648-55.

${ }^{94}$ Zhou and Zhang, 'Neutral theory in community ecology'.

${ }^{95}$ Smith and Lundholm, 'Variation partitioning as a tool to distinguish between niche and neutral processes'.

96 Houlahan J.E., Currie D.J., Cottenie K., Cumming G.S., Ernest S.K.M., Findlay C.S., Fuhlendorf S.D., U. Gaedke, Legendre P., Magnuson J.J., McArdle BH., Muldavin E.H., Noble D., R. Russell, R. D. Stevens, T. J. Willis, I. P. Woiwod, and S. M. Wondzell, 'Compensatory dynamics are rare in natural ecological communities', Proceedings of the National Academy of Sciences of the United States of America, 104/9 (2007), 3273-77.

97 Saetre P. and Bååth E., 'Spatial variation and patterns of soil microbial community structure in a mixed spruce-birch stand', Soil Biology and Biochemistry, 32/7 (2000), 909-17.

98 Smith and Lundholm, 'Variation partitioning as a tool to distinguish between niche and neutral processes'.

99 Layeghifard M., Makarenkov V., and Peres-Neto P.R., 'Spatial and species compositional networks for inferring connectivity patterns in ecological communities', Global Ecology and Biogeography, 24/6 (2015), 718-27. 
$\left.x^{2}, x^{3}\right)$. This approach is called trend-surface analysis ${ }^{100}$. The disadvantage of this method is that it models large-scale patterns, and detailed patterns cannot be accounted for using it. The principal coordinates of neighbor matrices method (PCNM) is able to identify spatial patterns in a significant range of scale levels ${ }^{101}$. The PCNM method generates a large number of orthogonal variables (PCNM functions) that model the spatial relationships of sampling points ${ }^{102}$. For this purpose a matrix of Euclidean distances between sampling points is constructed. Then a boundary is set below which the distance is estimated, and above that the distance is taken as "very large" and estimated as four times the threshold value. Based on the modified truncated distance matrix, the principal coordinates are analyzed. For further analysis only principal coordinates (aka PCNM functions or PCNM variables) corresponding to positive eigennumbers of the truncated distance matrix are used. Then, according to the principle of parsimony, the PCNM variables that best describe the observed properties of biological communities are selected. For this purpose, the forward selection procedure is most commonly used ${ }^{103}$.

\section{Ecogeographic predictors of the ecological niche derived from remote sensing data}

The development of multichannel satellite imagery and technologies for constructing three-dimensional terrain models create new opportunities for studying the links between species and environmental conditions and assessing the quality of habitats. This work uses materials from the Operational Land Imager (OLI) toolkit installed on the Landsat 8 (Geological Survey (U.S.), and EROS Data Center. 1900. EarthExplorer. [Reston, Va.]: U.S. Dept. of the Interior, U.S. Geological

${ }^{100}$ Gilbert B. and Bennett J.R., 'Partitioning variation in ecological communities: Do the numbers add up?', Journal of Applied Ecology, 47/5 (2010), 1071-82; Lichstein J.W., Simons T.R., Shriner S.A., and Franzreb K.E., 'Spatial autocorrelation and autoregressive models in ecology', Ecological Monographs, 72/3 (2002), 445-63.

101 Legendre P., Borcard D., and Peres-Neto P.R., 'Concep Ts \& Synthesis Emphasizing New Ideas To Stimulate Research in Ecology Analyzing Beta Diversity: Partitioning the Spatial Variation of Community Composition Data', Ecological Monographs, 75/4 (2005), 435-50.

102 Blanchet F.G., Legendre P., and Borcard D., 'Modelling directional spatial processes in ecological data', Ecological Modelling, 215/4 (2008), 325-36.

${ }^{103}$ Gendreau-berthiaume, 'Lab 9 - Spatial analysis : Trend surface analysis and PCNM'; Blanchet, Legendre, and Borcard, 'Modelling directional spatial processes in ecological data'. 
Survey. http://purl.access.gpo.gov/GPO/LPS82497). Images of the Earth's surface were taken in the year of animal species counting - April 27 and July 20, 2013. The multispectral scanners of Landsat 8 satellites enable the assessment of reflected radiation in the wavelength band of $0.433-1.390 \mathrm{~m}$ with a spatial resolution of $30 \times 30 \mathrm{~m}$ in the ground (imaging channels $1-7,9$ ) and in panchromatic channel with $15 \times 15 \mathrm{~m}$ resolution (imaging channel 8), thus covering the most part of solar radiation spectrum. Imaging is carried out in nine spectral bands (channels) (symbols - B1-B9), corresponding to the main windows of atmospheric transparency, which ensures optimal display of energy characteristics for the waves whose length corresponds to the maximum perception by the active surface ${ }^{104}$. Along with the direct values of the Landsat channels, the properties of the environment are selectively reflected through their ratios (indices) ${ }^{105}$ (Table 1).

Aerosol Coast Index (aerosol/coastal) (AC-Index):

\section{(B1-B2)/(B1+B2).}

The index is named after channel B1, the coast and aerosol channel. This channel is sensitive to atmospheric aerosol concentrations. Another important property of this channel is the ability to inspect shallow coastal and inland waters to estimate sediments, organic matter, coral reefs, and plankton containing chlorophyll. In addition to these capabilities, this index can also be used to estimate the density of certain types of vegetation, since many plants have epicuticular waxy covers that reflect harmful ultraviolet rays (http://surfaceheat.sites.yale.edu/sites/default/files/Coastal\%20Aerosol\% 20Band_1.pdf). Due to the fact that among Landsat satellites such a channel appeared for the first time, there is still very little actual data on the application of this index.

Hydrothermal Composite, Iron Oxide Index (Hydr):

\section{B4/B2.}

Clay Minerals (Clay), and Simple tillage index (STI):

\section{B6/B7.}

104 Santos N.D. and Gonçalves G., 'Remote Sensing Applications Based on Satellite Open Data (Landsat8 and Sentinel-2)', (2014), 1-10.

${ }^{105}$ Kunah O.M. and Papka O.S., 'Ecogeographical determinants of the ecological niche of the common milkweed (Asclepias syriaca) on the basis of indices of remote sensing of land images', Visnyk of Dnipropetrovsk University. Biology, ecology, 24/1 (2016), 78-86. 
Table 1

Typology of Landsat 8 OLI (Operational Land Imager) and TIRS (Thermal Infrared Sensor) indices

\begin{tabular}{|c|c|c|c|c|c|c|}
\hline & Band_2 & $\begin{array}{c}\text { Band_ } \\
3\end{array}$ & Band_4 & Band_5 & Band_6 & Band_7 \\
\hline Band_1 & AC-Index & & & & & M15 \\
\hline Band_2 & & & Xantophil & $\begin{array}{c}\text { GreenNDV } \\
\text { I }\end{array}$ & $\begin{array}{c}\text { MND } \\
\text { W }\end{array}$ & \\
\hline Band_4 & & & & NDVI & & Lomposite \\
\hline Band_5 & & \multicolumn{2}{|c|}{ Chlorophill a } & & & $\begin{array}{c}\text { NBR } \\
\text { Band_6 }\end{array}$ \\
& & & & $\begin{array}{c}\text { Mineray } \\
\text { VI, } \\
\text { Normalized } \\
\text { Difference } \\
\text { Tillage } \\
\text { Index } \\
\text { (NDTI) }\end{array}$ \\
\hline
\end{tabular}

Through the following conversion a Normalized Difference Tillage Index (NDTI) can be obtained ${ }^{106}$ :

$$
N D T I=\frac{S T I-1}{S T I+1} .
$$

Normalized difference vegetation index (NDVI):

(B5 - B4)/(B5 + B4).

Green NDVI (GreenNDVI) - very sensitive to chlorophyll concentrations:

(B5-B3)/(B5+B3).

Chlorophyll a concentration index:

B5/(B3+B4).

Xanthophyll activity index (NDB4B3):

(B3 - B4)/(B4 + B3).

Vegetation index - takes into account differences in biomass and features of vegetation types (VI):

(B6 - B7)/(B7 + B6).

106 A.P. Van Deventer, A. D. Ward, P. M. Gowda, and J. G. Lyon, 'Using thematic mapper data to identify contrasting soil plains and tillage practices', Photogrammetric Engineering and Remote Sensing, 63/1 (1997), 87-93. 
Normalized difference water index - sensitive to water content in green biomass (MNDW):

\section{$(\mathbf{B 3}-\mathbf{B 6}) /(\mathbf{B 3}+\mathbf{B 6})$.}

Land Surface Water Index (Land Surface Water Index, Normalized Difference Infrared Index - LSWI) ${ }^{107}$ :

(B5 - B6)/(B5+B6).

Normalized Burn Ratio (NBR) ${ }^{108}$ :

(B5 - B7)/(B5+B7).

The M15 index is sensitive to tillage technology and can be considered as a variant of the arable index ${ }^{109}$ :

\section{(B2 - B6)/(B2+B6).}

\section{Ecogeographic predictors of ecological niche derived from digital elevation model}

We used information from the Shuttle Radar Topography Mission (SRTM) at $30 \mathrm{~m}$ pixel resolution to construct a digital elevation model. The $30 \mathrm{~m}$ resolution is suitable for small- and medium-scale analysis, but for more detailed purposes it is very coarse. The digital model was interpolated using kriging ${ }^{110}$. After this operation, the level of detail of the original model does not change, but a surface is obtained where there is coherence of angular properties (i.e., slope and aspect) between neighboring pixels ${ }^{11}$, which is very important for quantitative analysis of the land surface. Based on the digital elevation model, indicators such as slope and curvature of the land surface, as well as the topographic moisture index, were estimated along with the altitude above sea level.

${ }^{107}$ P. Li, L. Jiang, and Z. Feng, 'Cross-comparison of vegetation indices derived from landsat-7 enhanced thematic mapper plus (ETM+) and landsat- 8 operational land imager (OLI) sensors', Remote Sensing, 6/1 (2013), 310-29.

${ }^{108} \mathrm{Li}$, Jiang, and Feng, 'Cross-comparison of vegetation indices derived from landsat-7 enhanced thematic mapper plus (ETM+) and landsat-8 operational land imager (OLI) sensors'.

109 Van Deventer, Ward, Gowda, and Lyon, 'Using thematic mapper data to identify contrasting soil plains and tillage practices'.

${ }^{110}$ Bernardes T., Gontijo I., Andrade H., Vieira T.G.C., and H.M.R. Alves, 'Digital Terrain Models Derived from SRTM Data and Kriging', Innovations in 3D Geo Information Systems, (2006), pp. 673-82.

${ }^{111}$ Marder L., Corbellini V.A., Ferrão M.F., Scroferneker M.L., and Schneider R.D.C.D.S., 'Quantitative analysis of total mycotoxins in metabolic extracts of four strains of Bipolaris sorokiniana (Helminthosporium sativum)', Process Biochemistry, 41/1 (2006), 177-80. 
Topographic wetness index

The concept of topographic wetness index (TWI) was first proposed by C. Biven and N. Kirkby ${ }^{112}$. The topographic wetness index is calculated by the formula:

$\mathrm{TWI}=\ln (\mathrm{a} / \tan \beta)$,

where a is drainage area (catchment area calculated per unit length of the closing contour), $\beta$ is slope steepness ${ }^{113}$.

Topographic position index

The Topographic position index (TPI) is the difference between the absolute height of a given point (or cell) and the average height of points in a particular buffer around the source point. Positive TPI values correspond to convexities of the land surface; negative values correspond to depressions; values close to zero can indicate either a flat surface or a mid-slope ${ }^{114}$.

\section{Geomass Balance Index}

The Geomass Balance Index reveals the topographic prerequisites for soil failure and deposition. This index identifies areas with a high probability of slope failures ${ }^{115}$. Negative index values indicate areas with geomass accumulation, such as relief depressions or floodplains. Positive values indicate areas of high erosion risk. An index value close to zero indicates areas with an equilibrium of geomass loss and gain.

The LS erosion factor

The LS elevation erosion potential is one component of the Universal Soil Loss Equation (USLE). LS is the product of the L- and S-factors. The L-factor determines the slope length and the S-factor determines the slope steepness. The Universal Soil Erosion Loss Equation (USLE), or Wischmeier and Smith's equation, was derived in the United States as a method of calculating average annual soil loss based on a generalization of observations on standard runoff plots $22.13 \mathrm{~m}$ long and with a slope of

112 Beven K.J. and Kirkby M.J., 'A physically based, variable contributing area model of basin hydrology', Hydrological Sciences Bulletin, 24/1 (1979), 43-69.

113 J. P. W. I. D. Moore, 'Length-slope factors for the Revised Universal Soil Loss Equation: Simplified method of estimation', Journal of Soil and Water Conservation, 47 (1992), 423-28.

${ }^{114}$ Guisan A., Weiss S.B., and Weiss A.D., 'GLM versus CCA spatial modeling of plant species distribution', Plant Ecology, 143/1 (1999), 107-122.

115 Möller M., Volk M., Friedrich K., and Lymburner L., 'Placing soil-genesis and transport processes into a landscape context: A multiscale terrain-analysis approach', Journal of Plant Nutrition and Soil Science, 171/3 (2008), 419-30. 
$9 \%$ conducted at more than 8,000 sites in 21 states $^{116}$. The first version of the USLE used a tangent to describe the effect of slope steepness and a constant value of 0.5 for the index of degree at slope length. Later, the tangent of the slope angle was replaced by sine, because it was found that this function could more accurately reflect the effect of slope on slopes steeper than $3^{0^{117}}$. Soil erosion losses are much more sensitive to changes in slope steepness than to changes in length, so the improved USLE - RUSLE model was aimed at the most accurate assessment of the slope steepness factor ${ }^{118}$.

\section{Direct and diffuse insolation}

Direct and diffuse insolation belong to the category of topoclimatic indicators $^{119}$. The most distinctive variations in climatic patterns arise from topoclimatic processes occurring in the Earth's boundary layer and having a characteristic dimension of no more than $101 \mathrm{~km}$ (meso $\beta$ scale) and up to $10-3 \mathrm{~km}$ (micro $\beta$ scale) (scale levels are given according to Orlanski ${ }^{120}$ ). Topoclimatology is part of climatology, which studies the impact of the Earth's surface on climate. The earth's surface predominantly controls the spatial differentiation of surface atmospheric processes and associated climate variations ${ }^{121}$. Solar radiation hitting the Earth's surface consists of two components, shortwave and longwave. In order to calculate the shortwave component, an estimate of the direct and diffuse components that reach the exposed surface must be taken into account, with an estimate of all the effects that are caused by the surface topography and specific to each component ${ }^{122}$.

To describe the primary productivity of ecosystems, the calculation of potential (maximum) values of total and photosynthetically active

116 Wischmeier W.H. and Smith D.D., (1978) 'Predicting rainfall erosion loss: A guide to conservation planning. Agricultural Handbook No. 537.

${ }^{117}$ Wischmeier W.H. and Smith D.D., (1978) 'Predicting rainfall erosion loss: A guide to conservation planning. Agricultural Handbook No. 537.

${ }^{118}$ Renard K.G., Meyer L.D., and Foster G.R., 'Revised Soil Universal Soil Loss Equation', (1997), 1-18.

119 Böhner J. and Antonić O., 'Chapter 8 Land-Surface Parameters Specific to Topo-Climatology', Geomorphometry: Concepts, software, applications, (2009), pp. 195-226.

120 Orlanski J., 'A rational subdivision of scales for atmospheric processes', Bulletin of the American Meteorological Society, 56 (1975), 527-30.

121 Böhner and Antonić, 'Chapter 8 Land-Surface Parameters Specific to Topo-Climatology'.

122 Böhner and Antonić, 'Chapter 8 Land-Surface Parameters Specific to Topo-Climatology'. 
radiation (PAR), i.e., the part of solar energy that can be used by plants for photosynthesis, is of particular importance. The PAR modeling is based on information about the geographical location of the territory (latitude and longitude) and certain model characteristics of the atmosphere. The digital elevation model can be applied to estimate the influence of the relief on the solar energy distribution pattern. The PAR consists of two components of total solar radiation, direct and scattered, and can be calculated using the formula:

$$
\mathrm{PAR}=0.6 \mathrm{SR}+0.4 \mathrm{DR}
$$

where $R R$ is the amount of scattered radiation and RP is the amount of direct radiation.

Altitude above channel network

Altitude above channel network, or Vertical Distance to Channel Network (VDTCN), is the difference between elevation and channel network height ${ }^{123}$ (Figure 1). It is a reliable marker of the water table and can be used for soil mapping ${ }^{124}$.

\section{Multiresolution upland ridge index and multiresolution valley bottom index}

The Multiresolution valley bottom flatness (MRVBF) algorithm for calculating the multiscale talus index identifies talus based on the following assumptions: (1) talvegs are more elevated and below their surroundings; (2) talvegs occur over a wide range of scales; and (3) larger talvegs are flatter than smaller talvegs ${ }^{125}$. Index values of less than 0.5 indicate that the area in question is not a talus. Values of 0.5-1.5 indicate the steepest and smallest talvegs. Flatter and larger talvegs are labeled with index values greater than 2.5. Multiresolution ridge top flatness index (MRRTF) is a complementary index to the previous index. In most cells of the raster, one of the indices (MRVBF or MRRTF) will have a value less than 0.5 , which will indicate either the presence of elevation or talus. If both indices have a value less than 0.5 , then the area will be referred to a slope.

${ }^{123}$ Potapenko O., Kunah O.M., and Fedushko M.P., 'The effect of technological oil spill in soil within electrical generation substations, analysed by ecological regime in the context of relief properties', Biosystems Diversity, 27/1 (2019), 43-50.

124 Eisank C., Smith M., and Hillier J., 'Assessment of multiresolution segmentation for delimiting drumlins in digital elevation models', Geomorphology, 214 (2014), 452-64.

125 Gallant J.C. and Dowling T.I., 'A multiresolution index of valley bottom flatness for mapping depositional areas', Water Resources Research, 39/12 (2003). 


\section{Vector Ruggedness Measure}

The Vector Ruggedness Measure (VRM) estimates the variance of vectors orthogonal to the terrain surface. The VRM value is low for both flat and steep terrain, but high for steep and rugged terrain ${ }^{126}$. Ruggedness is understood as the non-smoothness of the surface.

\section{Assessment of the parameters of the ecological niche of mole-rat} (Spalax microphthalmus Guldenstaedt, 1770) at the landscape level

The polygon to study the features of the ecological niche of mole-rat (Spalax microphthalmus Guldenstaedt, 1770) at the landscape level was laid within the watershed-beam landscape. The polygon is located on the right bank of the Dnieper River near the villages Lubimovka and Pershe Travnya (Dnepropetrovsk district) (Fig. 1). The highest part of the relief in the studied area is called Mogyla Yatsova mound $(155.5 \mathrm{~m})$. Ternovaya Ravine is the southeastern spur of the larger Bolshaya Tatarka Ravine. The vegetation of Ternovaya Ravine is represented mainly by steppe complexes on the slopes and meadow or meadow-bog complexes in the thalweg. There are fragmentary artificial forest plantations. The gully slopes due to erosion are not suitable for agricultural use, so the natural vegetation cover is preserved on them. Meadow communities in the thalweg are used as pastures for cattle. North of the village of Pershe Travnya is the mouth of the bayrak Yatsev Yar. According to O.L. Belgard ${ }^{127}$, the forest communities of this byrak belong to the southern geographic variant.

The feature of these complexes is predominantly afforested slopes of the northern exposure, while the slopes of the southern exposure can remain without forest cover. Forest vegetation significantly reduces the intensity of erosion processes, as a result of which the slopes of bayrak have a higher slope than unforested gully. It is the bayrak and gully that are the main places of mole vole pores concentration. A significant part of the study area is occupied by agricultural lands. They are located in the upland habitats.

${ }^{126}$ Sappington J.M., Longshore K.M., and Thompson D.B., 'Quantifying Landscape Ruggedness for Animal Habitat Analysis: A Case Study Using Bighorn Sheep in the Mojave Desert', Journal of Wildlife Management, 71/5 (2007), 1419-26.

${ }^{127}$ Бельгард, Лесная растительность Юго-Востока УССР. 


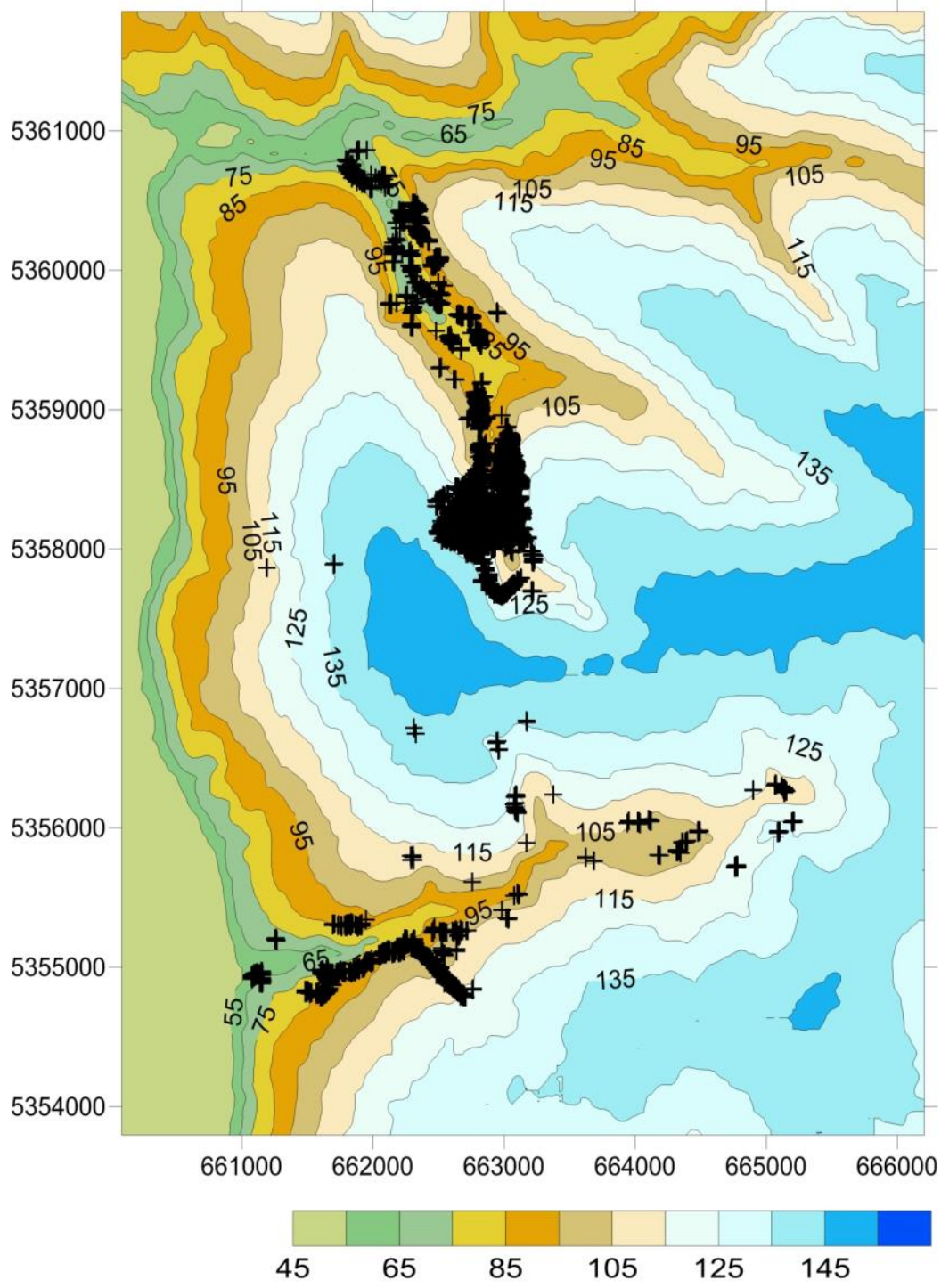

Fig. 1. Digital elevation model: the crosses indicate the location of the mole-rat mounds. The legend shows the elevation of the relief in meters above sea level. Coordinates are given in UTM system, zone 36 
Within them, because of regular mechanical tillage of soils, the porpoises are preserved for a very short time and their density is very low. The total area of the studied polygon was $49.6 \mathrm{~km}^{2}$. A total of 7,554 mole-rat mounds were identified. The area of the convex polygon, which limits the area of the identified mole-rat mounds location, was 15.05 $\mathrm{km}^{2}$. The raster maps of environmental variables - vegetation indices of Landsat satellite images (Fig. 2), the digital elevation model (Fig. 3), and derived relief features (Fig. 4) were used to describe the ecological space within which the mole-rat ecological niche exists. A preliminary analysis of the distribution of mole-rat mounds along the axes of the ecological space indicates a certain selection of the conditions offered by the studied area by the animals.

The studied area has a variety of conditions, which is manifested in the variability of relief (elevation difference is $47-155.5 \mathrm{~m}$, the average value is $110.72 \mathrm{~m}$ ). The plateau areas are characterized by a relatively even surface $\left(0-2^{\circ}\right)$. They are all tilled and include agricultural fields or artificial forest strips. There is a ravine-gully system with the remnants of natural steppe vegetation and slopes of varying degrees of erosion on the studied territory. Erosion processes in the gully in the absence of forest vegetation develop with greater intensity than in the byrak Yatsev Yar, so the width of the gully is much greater than the byrak. But the surface slope of the gully system is much less $\left(2-8^{\circ}\right)$ than that of the byrak. The steepness of the slopes in the byrak of Yatsev Yar is also due to granite outcrops, where the slope is represented by almost steep walls. In the gully system, the slope of the western exposure is steeper than the slope of the eastern exposure.

In Byrak, the slope of the southern exposure is steeper compared to the slope of the northern exposure. According to the degree of curvature of the earth's surface, it is possible to distinguish areas of convex curvature (positive curvature) - the upper thirds of slopes, concave (negative curvature) - the lower thirds of slopes and thalweg and areas of neutral curvature (kinks in the middle of slopes and plateau). 

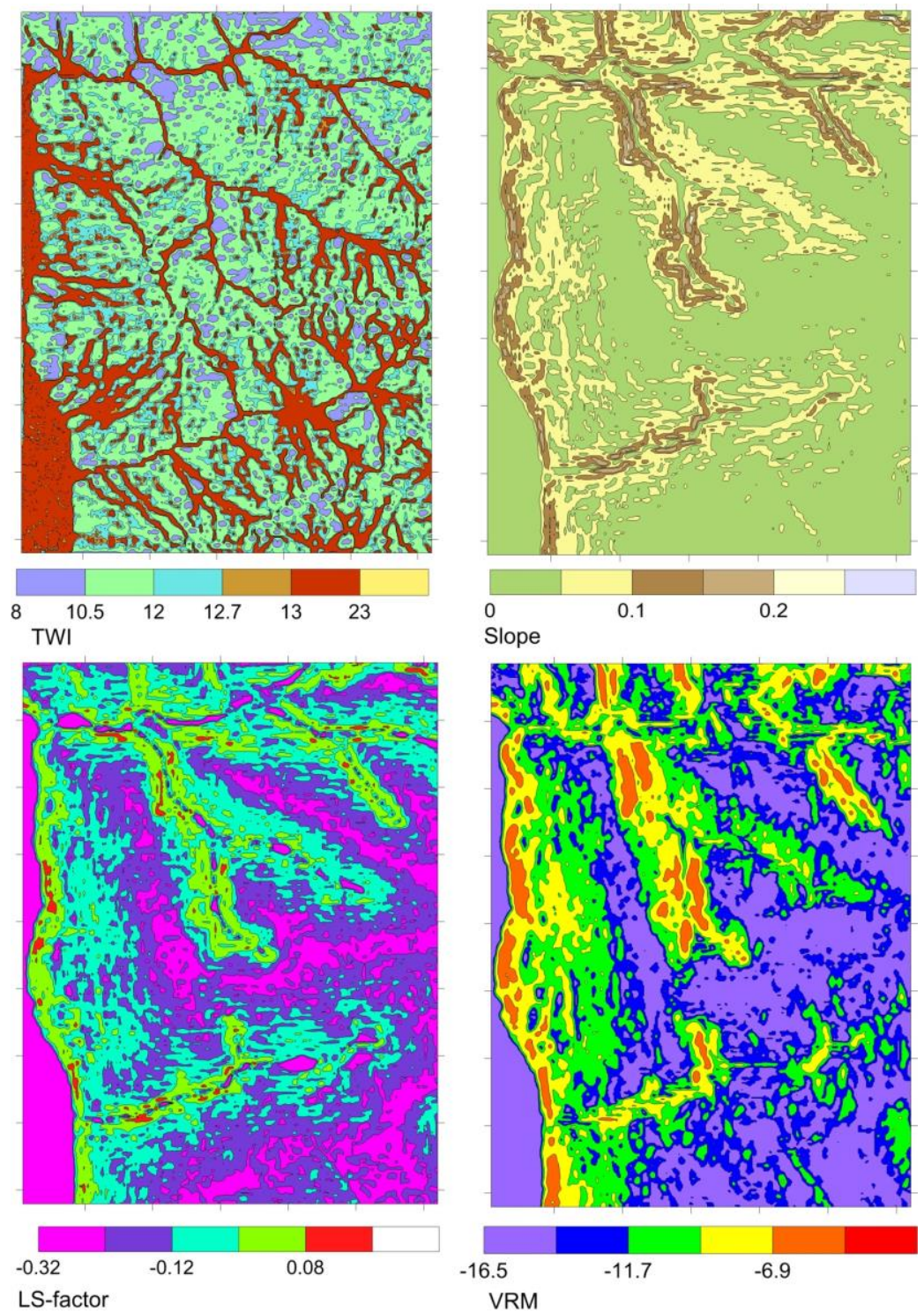

Fig. 2. Geomorphological layers 

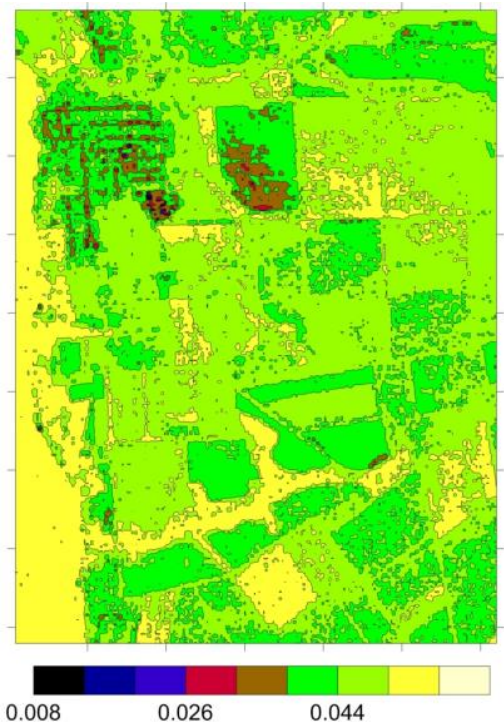

AC-Index
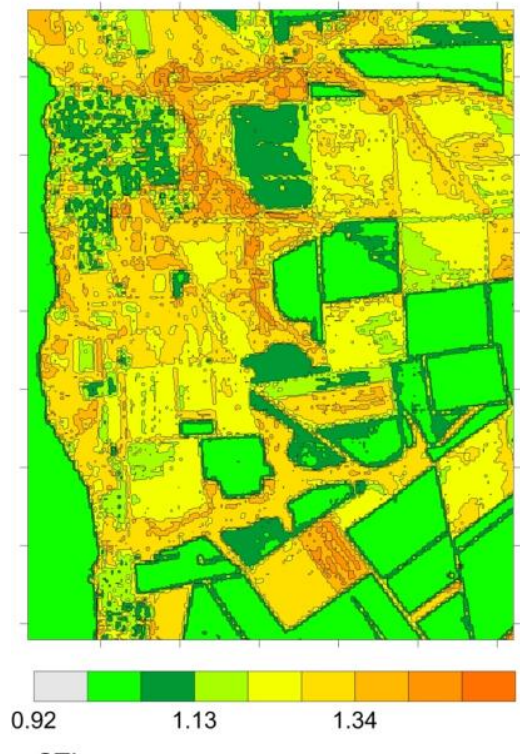

STI
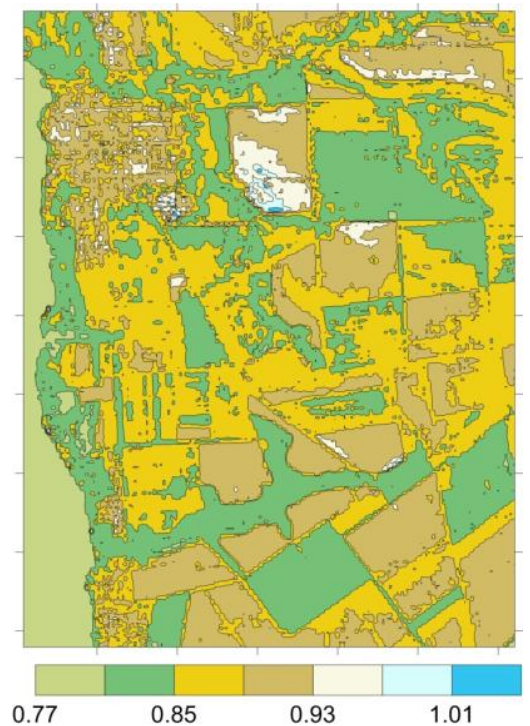

Hydrothermal Composite
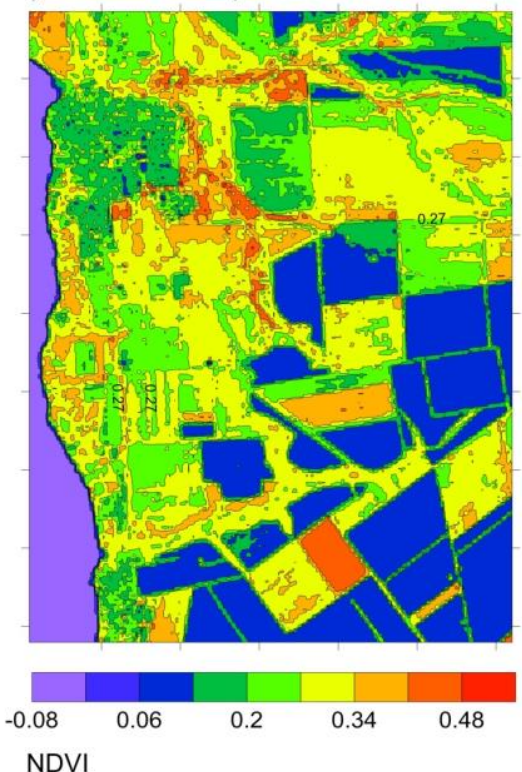

NDVI

Fig. 3. Indices derived from Landsat 8 imagery 

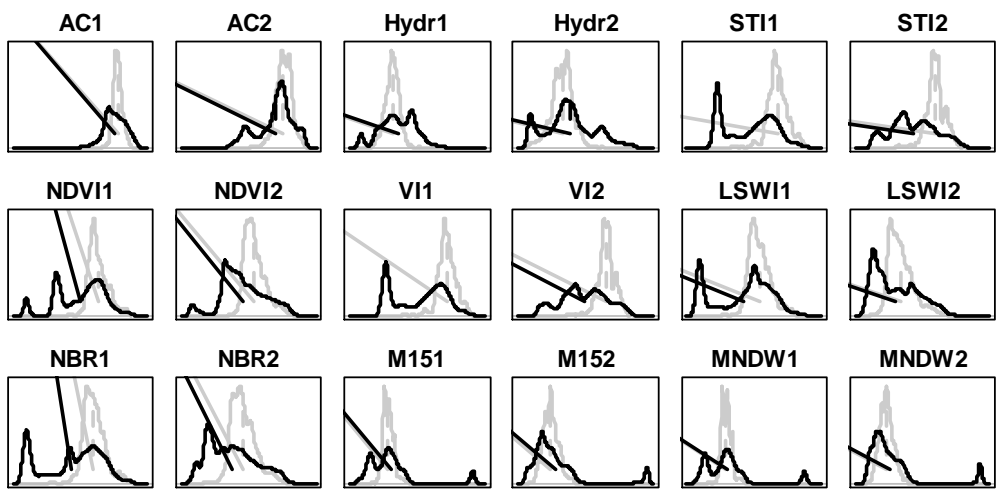

MNDW1
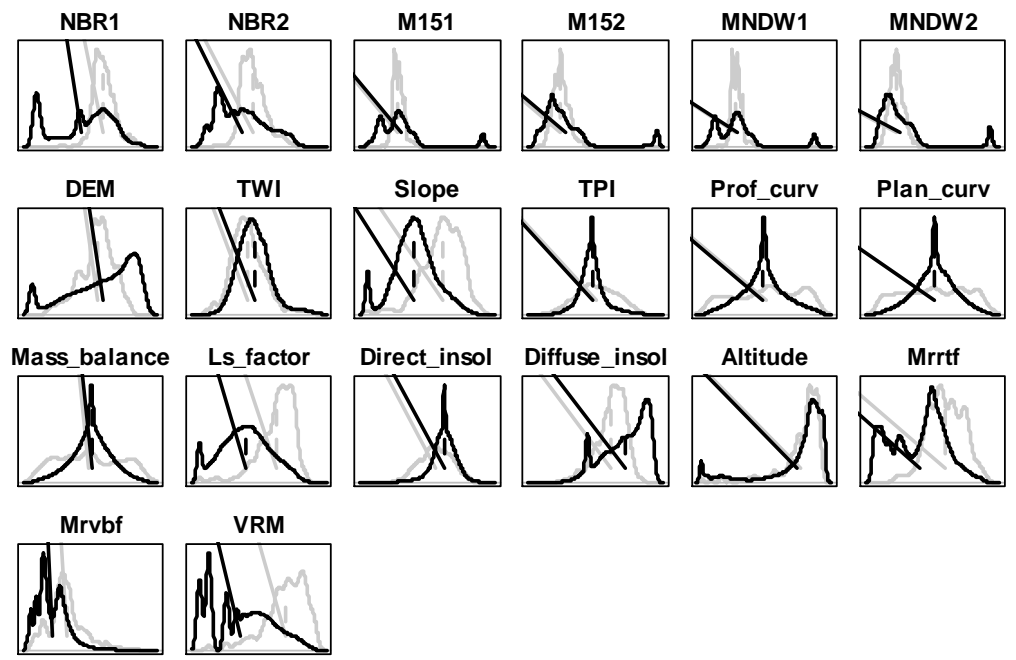

Fig. 4. Distribution of resources (dark lines) and distribution of resource exploitation (gray lines) by mole rats

The topographic wetness index reflects the complex pattern of redistribution of precipitation in the study area. It is possible to distinguish watershed areas with obvious moisture deficit due to local maxima of land surface elevation. The moisture deficit is also observed on steep slopes of byrak and gullies. The talwegs and plateau areas adjacent to watershed kinks are characterized by relatively better moisture availability. In the first stage of the study, the FANTER procedure was applied to compare the distribution of locales of mole rats (distribution of resource use) with the distribution of available resources in the ecological space. In the FANTER analysis, the axes of the space, to which both the largest and the smallest eigenvalues correspond, are 
important. To extract the appropriate number of axes, the criterion of sharp inflection of the column diagram of eigenvalues is used. Since the minimal eigenvalues are also important, it makes sense to construct a diagram with inverse values of eigenvalues (Fig. 5).
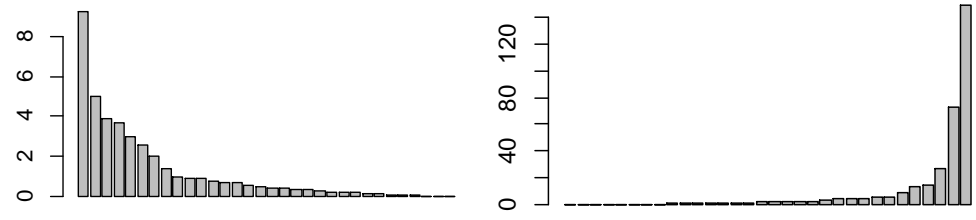

Fig. 5. Bar diagram of the distribution of the eigenvalues (left) and inverse eigenvalues (right) of the FANTER analysis

An examination of Figure 1 allows to distinguish the first and last two components (factors) of the FANTER analysis. The significance of the eigenvalues was tested using a randomized test (200 random samples were generated for which the eigenvalues were calculated). The test confirmed the significance of the eigenvalues $\left(\gamma_{1}=11.84, p<0.05\right.$; $\left.\gamma_{2}=5.53, p<0.099 ; \gamma_{31}=0.04, p<0.001 ; \gamma_{32}=0.03, p<0.001\right)$. The first components of the FANTER analysis reflect the marginal nature of the ecological niche, and the last components reflect specialization. The first component is most correlated with relief slope $(R=0.48)$, vector measure of terrain ruggedness $(R=0.47)$, erosion factor $L S(R=0.43)$, different scale indices of ridges Mrrtf and talvegs $\operatorname{Mrvbf}(R=0.35$ and 0.43 respectively) (Fig. 1, A). Of the indices derived from remote sensing data, the first component correlates significantly with vegetation index VI ( $\mathrm{R}=0.28$ and 0.23 for spring and summer) and the simple arable (clay minerals) index ( $\mathrm{R}=0.28$ and 0.23 for spring and summer). The combination of these indices indicates that the positive values of component 1 are clearly associated with the slopes of gullies of various degrees of erosion, which are covered with steppe vegetation. It is to these areas that the zone of the greatest pedoturbation activity of molerats is extruded. The second component is most strongly correlated with the curvature of the land surface $(R=-0.44)$ and the indices of space images taken in June and April. If we compare the factor coefficients of components 1 and 2 for Landsat indices, the Spearman correlation coefficient between them is 0.98 ( $\mathrm{p}<0.05)$. Thus, the first two components of the FANTER analysis reflect the same tendency for the marginal distribution of mole-rat mounds, expressed in terms of 
vegetation cover. The role of geomorphological determinants in the formation of ecological niche marginality, indicated by components 1 and 2, can be significantly different. This is especially evident in such indicators as the topographic wetness index and the multiscale thalweg index. In general, it can be recognized that components 1 and 2 of the marginality of the ecological niche of mole rats are very similar in their properties, which allows us to recognize the presence of one axis of marginality, which will be highlighted and discussed in terms of ENFAanalysis. Components 31 and 32 indicate the specialization of the ecological niche (Fig. 6, B). This pair of axes is characterized by considerable similarity in a series of ecogeographic indicators. The greatest (in terms of module) contribution to the specialization of the mole rats' niche is characterized by the M15 index, elevation of the relief, elevation above the channel network, and the hydrothermal composite. The mentioned ecogeographic variables indicate that the ecological optimum of mole rats' distribution occupies a certain area of the general gradient of geomorphological and vegetative conditions of the study area. This zone coincides to the greatest extent with the area of distribution of natural steppe vegetation remnants. It is important to note that along the axes of specialization, a series of Landsat indices obtained in the spring and summer time, factor loadings have the opposite sign. These features can also be considered as markers of steppe vegetation.

The results of the ENFA analysis are in agreement with the FANTER results. The randomized eigenvalues test indicates a significant specialization described by the first two components $(\mathrm{S} 1=149.70$, $\mathrm{p}=0.005 ; \mathrm{S} 2=72.43, \mathrm{p}=0.005)$. There is a clear inflection in the bar diagram of the eigenvalues of the components of specialization after the second component (Fig. 7), which allows to distinguish the first two components of specialization. The component that describes marginality is also statistically significant $(\mathrm{M}=15.54, \mathrm{p}=0.001)$. There is a strong correlation between specialization component S1 in the ENFA analysis and component 32 in the FANTER analysis $(\mathrm{R}=-1.00)$ and, respectively, between specialization component $\mathrm{S} 2$ and component 31 $(\mathrm{R}=-1.00)$ (Table 2). The marginalization of the ENFA analysis is naturally correlated with components 1 and 2 of the FANTER analysis ( $R=0.45$ and 0.25 , respectively). Obviously, the highly simplistic model that underlies the ENFA analysis cannot describe the complex configuration of the real ecological niche without distortion. The symmetric unimodal niche is a well-founded model for relatively stable ecological niches under near-optimal conditions. In our case, mole-rats 
are in the zone of their ecological optimum, but under conditions of intense anthropogenic transformation of their habitat. Therefore, the descriptive capabilities of FANTER analysis are more suitable for reflecting the features of the complex structure of the ecological niche than ENFA analysis.

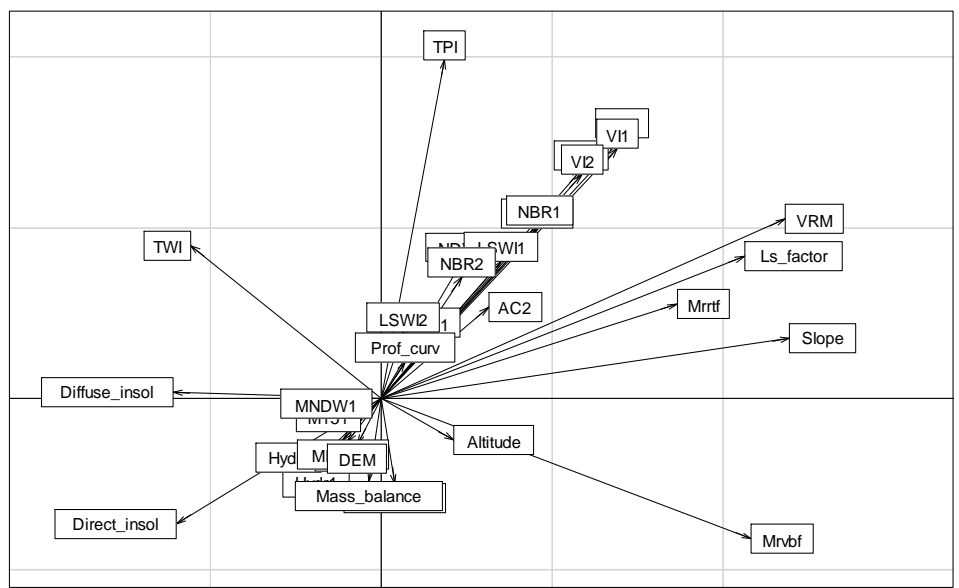

A

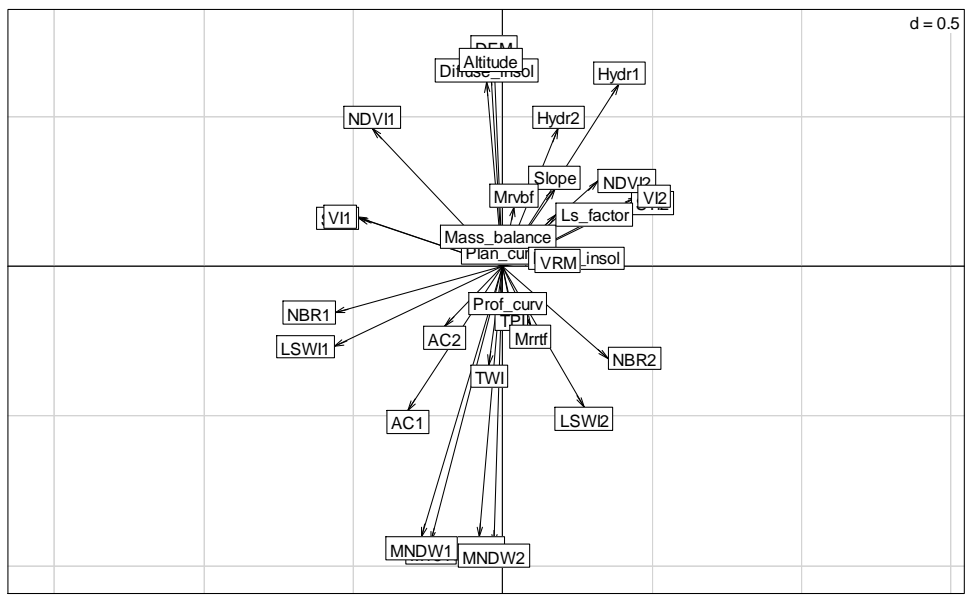

B

Fig. 6. Correlation between environmental variables and components 1 and 2 of the FANTER analysis (A) and 31 and 32 (B) 
Table 2

Correlation matrix between the components of the FANTER and ENFA analyses

\begin{tabular}{|c|c|c|c|c|}
\hline & \multicolumn{4}{|c|}{ FANTER } \\
\cline { 2 - 5 } & Component 1 & Component 2 & Component 31 & Component 32 \\
\hline $\mathrm{M}$ (Marginality) & 0.45 & 0.25 & -0.04 & 0.07 \\
\hline $\mathrm{S}_{1}$ (Specialization 1) & 0.00 & 0.00 & 0.00 & -1.00 \\
\hline $\mathrm{S}_{2}$ (Specialization 2) & 0.00 & 0.00 & -1.00 & 0.00 \\
\hline
\end{tabular}

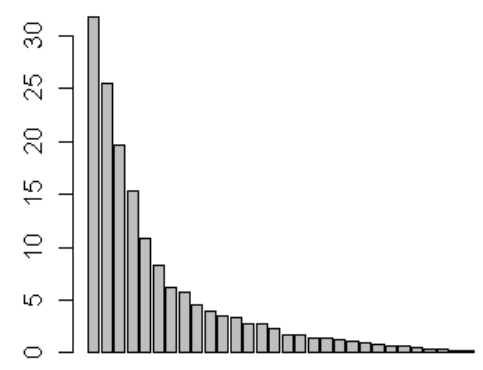

Fig. 7. Bar diagram of the distribution of the eigenvalues of the specialization components of ENFA analysis

However, it should be noted that the key features of marginalization and specialization of niche space are well enough reflected by ENFA analysis. The marginality of the niche according to the ENFA analysis is related to topography - mounds can be found most often on steep concave slopes (Fig. 8). The marginality of the ecological niche of the mole rat is most strongly determined by the VRM index (a vector measure of terrain roughness), erosion factor, surface slope, tillage index (clay mineral index), and vegetation index. Together, these indices clearly mark eroded terrain elements with remnants of natural steppe vegetation. Their marginal character is eloquently underlined by the name of the most informatively significant indicator - the measure of terrain ruggedness. It is in the most rugged part of the terrain, not suitable for agricultural use or practical application, displaced the zone of ecological optimum of the typical steppe soil dweller. 


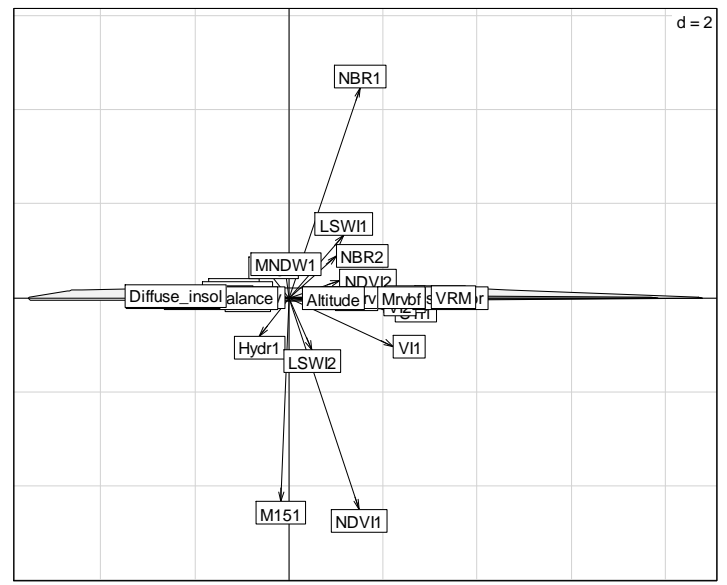

Fig. 8. Correlation between environmental variables and marginalization (abscissa axis) and specialization 1 (ordinate axis) of ENFA analysis

An important feature of the ecological niche established by ENFA analysis is the fact that geomorphological indices do not determine the niche specialization of a given animal. The key markers of the specialization axis are vegetation indices - NDVI, NBR, M15. Axis of specialization 1 is marked mainly by indices obtained for the spring period. Axis of specialization 2 is characterized by opposite signs of correlation coefficients for spring and summer periods. These features emphasize the importance in determining the configuration of the ecological niche of mole rat spring vegetation dynamics. The high pedoturbation activity of these animals should be supported by sufficient trophic resources supplied by actively vegetating plants.

The ENFA approach suggests the possibility of estimating the habitat preference index (Fig. 9). The results obtained indicate a low level of preference for both agrocenoses and territories of settlements by molerats. Nevertheless, in some types of agrocenoses conditions favorable for the life of these animals are created. It is quite probable that these territories can be used as dispersal areas for burros, which contributes to the maintenance of genetic diversity of populations of these animals. Certainly, the most favorable conditions are characterized by biogeocenoses which are included in the ravine and gully system with remnants of natural steppe vegetation and undisturbed soil cover. It should be pointed out that the ENFA-procedure for estimating the habitat 
preference index is mathematically less correct than the estimate that can be obtained using the MADIFA approach. MADIFA was conducted to calculate the habitat preference index more correctly. The randomized test confirmed the reliability of the first eigennumber in the MADIFA analysis $(\gamma 1=483.15, \mathrm{p}<0.05)$. The criterion of the sharp inflection of the eigennumber diagram allows us to distinguish the first component in the MADIFA analysis as significantly exceeding the next one in the eigennumber value (Fig. 1). In the MADIFA model, the ecological niche of the animal is represented as a sphere, and the region of the ecological space is deformed to the extent that the observed conditions differ from the region of the species' ecological optimum (Fig. 9, inset top left). The results indicate that the ecological niche of the blindflies occupies a small part of the ecological space of the considered polygon.

Component 1 of MADIFA reflects the main aspects of the difference between the observed conditions and the ecological optimum of the species. The main differences are observed in terms of the normalized difference water index, plowing index M15, vegetation indices (NDVI, VI), as well as height above the channel network and some other indices (Fig. 10). Component 2 indicates differences of the ecological space from the ecological optimum of gadflies by such indices as the Earth surface moisture index, NBR index, and elevation of topography.

The MADIFA components formally describe the nature of habitat differences from the ecological niche optimum. Comparison of the MADIFA axes with the ENFA axes allows us to interpret the nature of these differences in terms that describe the features of the niche as such marginality and specialization. Correlation analysis showed that MADIFA component 1 encompasses both marginality and specialization of the ecological niche of blindflies (Table 3). Component 2, which correlates with both marginality and specialization axes, is also of an integral nature.

The habitat preference index of mole-rats obtained using MADIFA (Fig. 11) differs significantly from the results of the ENFA procedure. The biogeocenoses of gully and gully systems are highlighted in the figure as the most preferred areas. Other types of landscape cover are categorized as the least preferred. In addition, within the lands with undisturbed vegetative and soil cover, gully slopes with steppe vegetation are clearly marked as the most preferred ones. The gully slopes and slopes with forest vegetation correspond to the ecological optimum of mole-rats to a lesser extent. A comparison of the results of the two approaches suggests that the ENFA approach reflects the degree 
of habitat preference to a greater extent if the potential niche is considered as the basis. Whereas the MADIFA approach reflects habitat preference from the perspective of a realized niche.

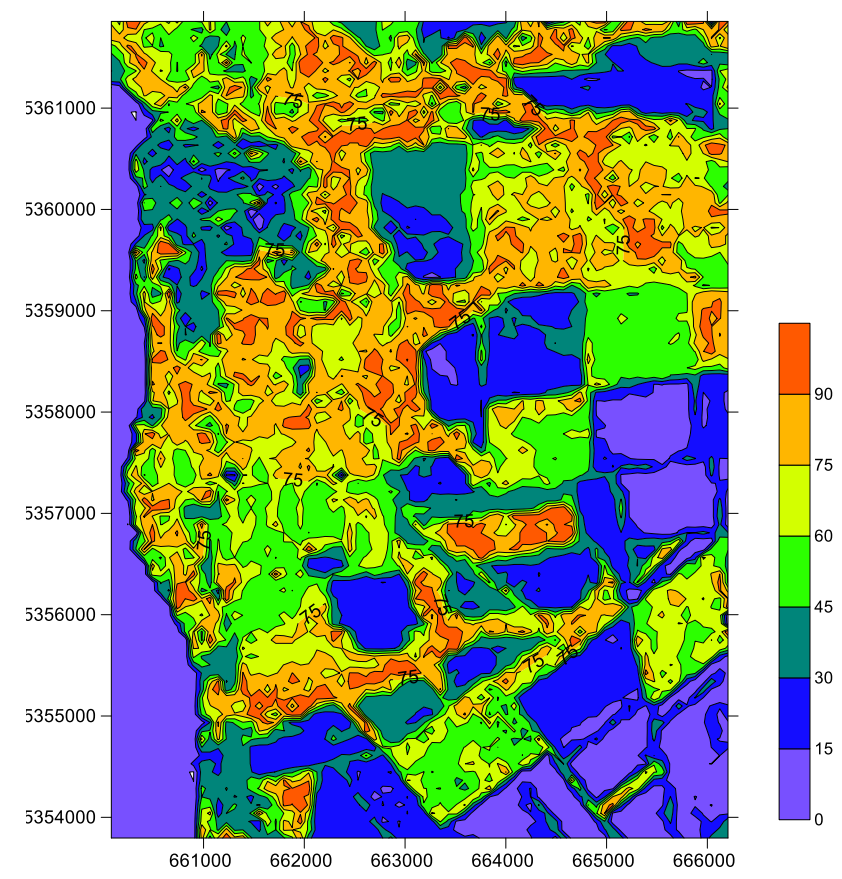

Fig. 9. ENFA-assessment of habitat preference index by mole rats

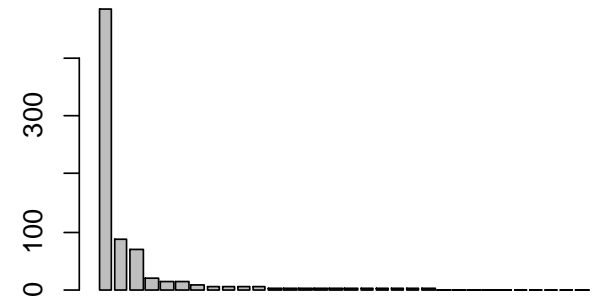

Fig. 10. Bar diagram of the distribution of the eigenvalues of the specialization components of the MADIFA analysis 


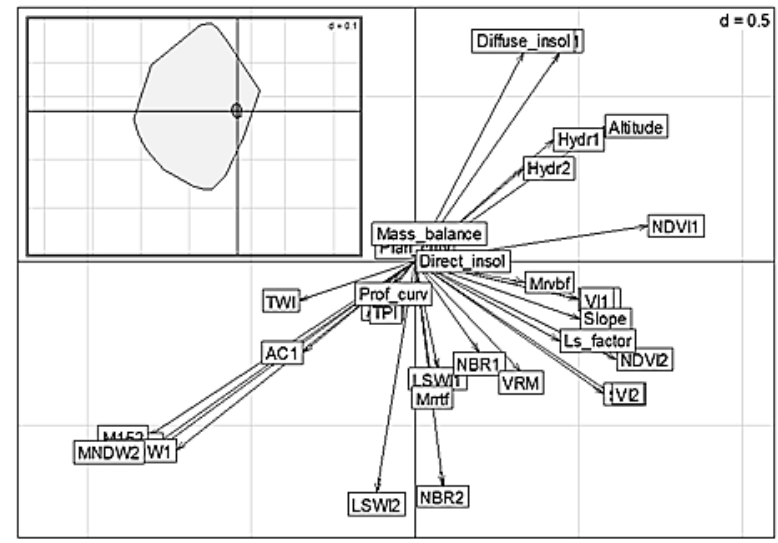

Fig. 11. Correlations of ecogeographic variables and MADIFA components. Top left box - correlation between the ecological niche of mole-rats (gray area) and the ecological space of the study area (light area) according to MADIFA results (abscissa axis - component 1, ordinate axis - component 2 of MADIFA)

Table 3

Correlation matrix between the components of MADIFA and ENFA analyses

\begin{tabular}{|c|c|c|c|}
\hline \multirow{2}{*}{ MADIFA } & \multicolumn{3}{|c|}{ ENFA } \\
\cline { 2 - 4 } & M (Marginality) & S1 (Specialization 1) & S2 (Specialization 2) \\
\hline Component 1 & 0,50 & $-0,84$ & $-0,09$ \\
\hline Component 2 & $-0,39$ & $-0,70$ & 0,42 \\
\hline
\end{tabular}

ENFA-approach indicates territories where dispersal of the species is possible, MADIFA-approach indicates territories where the species can be encountered with the highest degree of probability at a given time.

Clearly, these features of ecological niche factor analysis can be applied to a variety of practical problems in biodiversity conservation and management of soil biota resources. A combination of ENFA analysis and regression modeling has been proposed for spatial prediction of species distribution based on animal encounter data and environmental property covariates alone. In this approach, ENFA is used to generate so-called "pseudo-absence" data, which are then added to the original presence-only data to allow regression analysis. The problem with applying regression analysis to presence-only data is that we are only dealing with units $(1$ - species present), which means that no regression model can be applied to such data. To resolve the problem, a 
common approach is to introduce so-called "pseudo-absence points" simulating 0-data using probabilistic models, such as the ENFA method, to designate the area where a species is least likely to be encountered. The ENFA method is a type of factor analysis that applies species presence data to estimate the most preferred area of a species in an ecological property space, from which the distribution of the species in a geographic space can be predicted ${ }^{128}$. An ENFA analysis can result in a Habitat Suitability Index (HSI, ranging from 0 to 100\%). Based on the above logic, we proposed a procedure for assessing the role of scale in determining the parameters of the ecological niche. The well-known position regarding scale levels assumes the specificity of factors that determine the features of the phenomenon or process at the corresponding level of consideration. If the opposite is true, the hierarchical multilevel approach makes no sense - it is enough to find out the properties of the phenomenon of interest at any spatial level and it will be enough to extrapolate the obtained results to any other level.

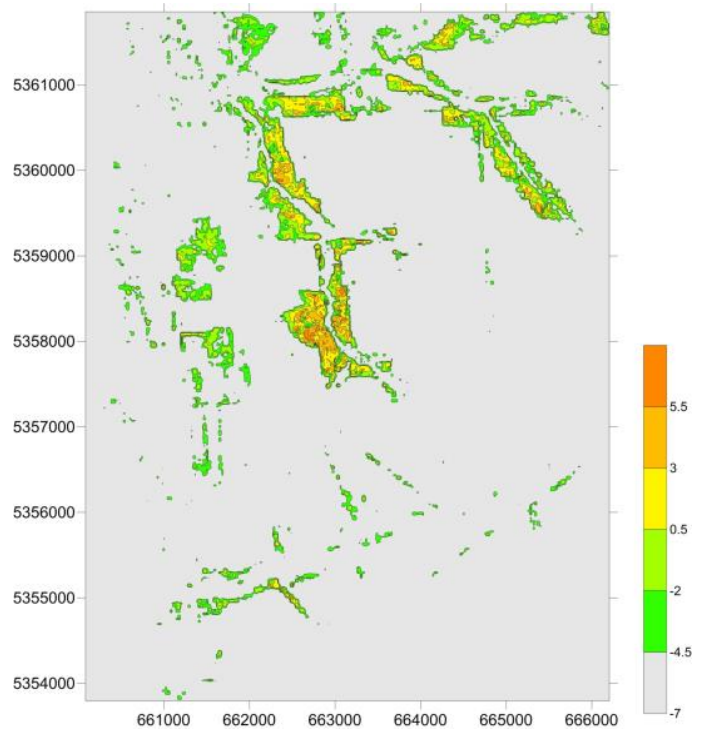

Fig. 12. MADIFA-assessment of the habitat preference index by mole rats (preference index is presented in logit-transformed form)

${ }^{128}$ Hirzel, Hausser, Chessel, and Perrin, 'Ecological-niche factor analysis: How to compute habitat-suitability maps without absence data?'. 
The given results of the analysis of the ecological niche of blindflies are based on two arbitrary positions. These are the dimensions of the space, within which the density and specifics of the location of the mounds were studied, and the scope of the polygon itself, within which the properties of the ecological niche were evaluated. Within the survey area, points of animal presence were established, and points of pseudoabsence were established within the entire polygon according to a regular grid. It is obvious that the ratio of these two areas can strongly influence the obtained result, not only the features of the ecological niche of the animal itself. The points of animal presence are an established fact, whereas the size and shape of the polygon from which the pseudoabsence points are extracted can vary greatly. Depending on this circumstance, we will get different results. Each of the obtained solutions will be correct, as it is a reflection of the hierarchical organization of the animal's ecological niche. We can set different conditions for the placement of pseudo-neutral points. The obtained estimates of the animal's ecological niche can act as aspects (angles of view) of the ecological niche in the context of a given condition. To cut off extremely unsuitable places for mole-rat life within the whole polygon we established a restriction within the primary habitat preference index, which was obtained on the basis of ENFA approach on the previous data analysis period, the criterion of $5 \%$ of suitability. Placement of pseudoabsence points in the zone of obviously unsuitable spaces (water surface, populated areas, asphalt roads) leads to trivial results. In this case, the markers of the corresponding spatial objects are anti-markers of the animal's ecological niche, which adds nothing to our knowledge of the peculiarities of animal life and ecology.

Next, we place the pseudo-absence points at different distances from the observed mounds of the mole rats - 100, 200, 500, 750, 1000, and $3000 \mathrm{~m}$. Accordingly, each time we perform the ENFA procedure and set the parameters of marginality and specialization (Fig. 13). The closest placement of pseudo-absence points from thresholds (not more than $100 \mathrm{~m}$ ) shows the specifics of the choice of the most preferred activity zones within a scale level commensurate with the extent of the biogeocenosis. The extreme values of the range of maximum remoteness of pseudo-absence points allow us to identify landscape level factors that determine the ecological niche of mole rats. Since the axis of marginality is the only one within the ENFA-approach, the results obtained at different levels of analysis are successive. The role of factor loadings of specialization axes can be redistributed between several axes at different 
scale levels, which requires consideration of several rather than one axis of specialization for the picture to be complete. Therefore, for clarity of presentation, we decided to focus only on the discussion of the marginal properties of the ecological niche of mole rats at different scale levels.
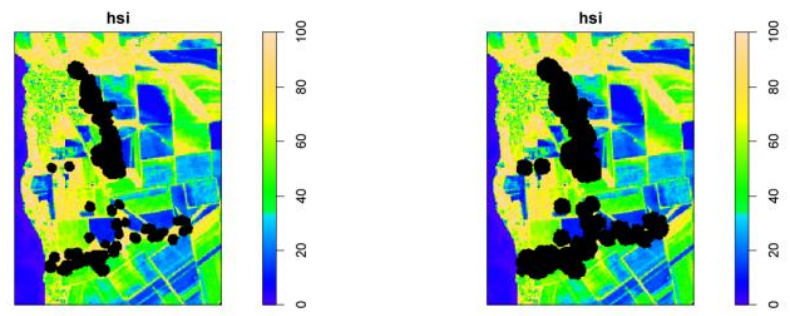

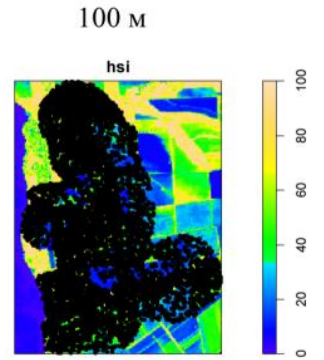

$1000 \mathrm{M}$

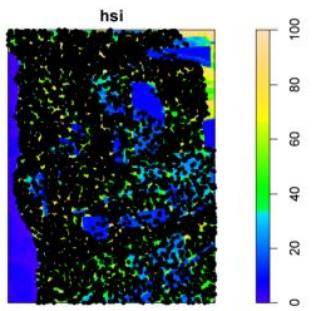

$3000 \mathrm{M}$

Fig. 13. Location of pseudo-absence points $(7000 \mathrm{pc})$ as a function of different boundary distances from the nearest mound

The evaluation of the marginal parameters of the ecological niche of mole-rats at different scale levels showed a regular variability of the niche properties depending on the spatial context (Fig. 14). For the AC-index, a local maximum of marginality was observed during the spring and summer observations in the range of mean values of the maximum distance of pseudo-absence counting points. Both in the range of dimensions close to the dimensionality of the biogeocenosis and close to the dimensionality of the landscape, the marginality of this index decreases. For the hydrothermal composite, marginality increases 
monotonically with increasing range of consideration of the ecological niche. A similar pattern is also characteristic of the arable STI index, aka clay mineral index. Both indices are markers of eroded slopes. This indicates that the ecological niche of the mole rats, as shown earlier, is displaced to the zone of sloping lands with the highest level of development of erosion processes. But the optimum of the ecological niche within such habitats is closest to the less eroded areas, which are represented on the slopes. This raises the question whether mole rats cause the less erodible slopes, or whether they choose such sites. Separate studies at the appropriate spatial level are needed to resolve this question. The vegetation indices NDVI and VI show a trend of increasing marginality with increasing distance (summer data) and with the same trend, a local minimum is observed for these indices in spring. For the LSWI and NBR indices, there is a local minimum of marginality for the spring data and a local maximum for the summer data. For the M15 index, there is a tendency for a monotonic decrease in marginality with increasing distance. Thus, for all Landsat indices, which predominantly describe the state of vegetation cover and, to some extent, of soil cover, the variability of estimates of the marginality of the ecological niche of mole rats is observed. The similar patterns are also established for the marginality of ecogeographic variables on the basis of geomorphological indices (Fig. 15). The marginalities of terrain elevation and topographic moisture index monotonically decrease as the range of spatial coverage of the terrain increases. At its limit, elevation marginality has a negative value. This suggests that throughout the range, mole-rats prefer lower elevations (negative marginality), as they are displaced by human economic activity from upland upland plateau habitats. But at the local level, these animals prefer more drained areas (positive marginality). Also at the local level, the degree of marginality on potential moisture conditions, expressed by the TWI index, is the highest, since within the biogeocenosis animals prefer stations with the highest moisture conditions (under condition of sufficient drainage) to form a more productive plant community. The marginality of the slope angle increases monotonically with the growth of the maximum distance from the nearest mound of the mole rats. 

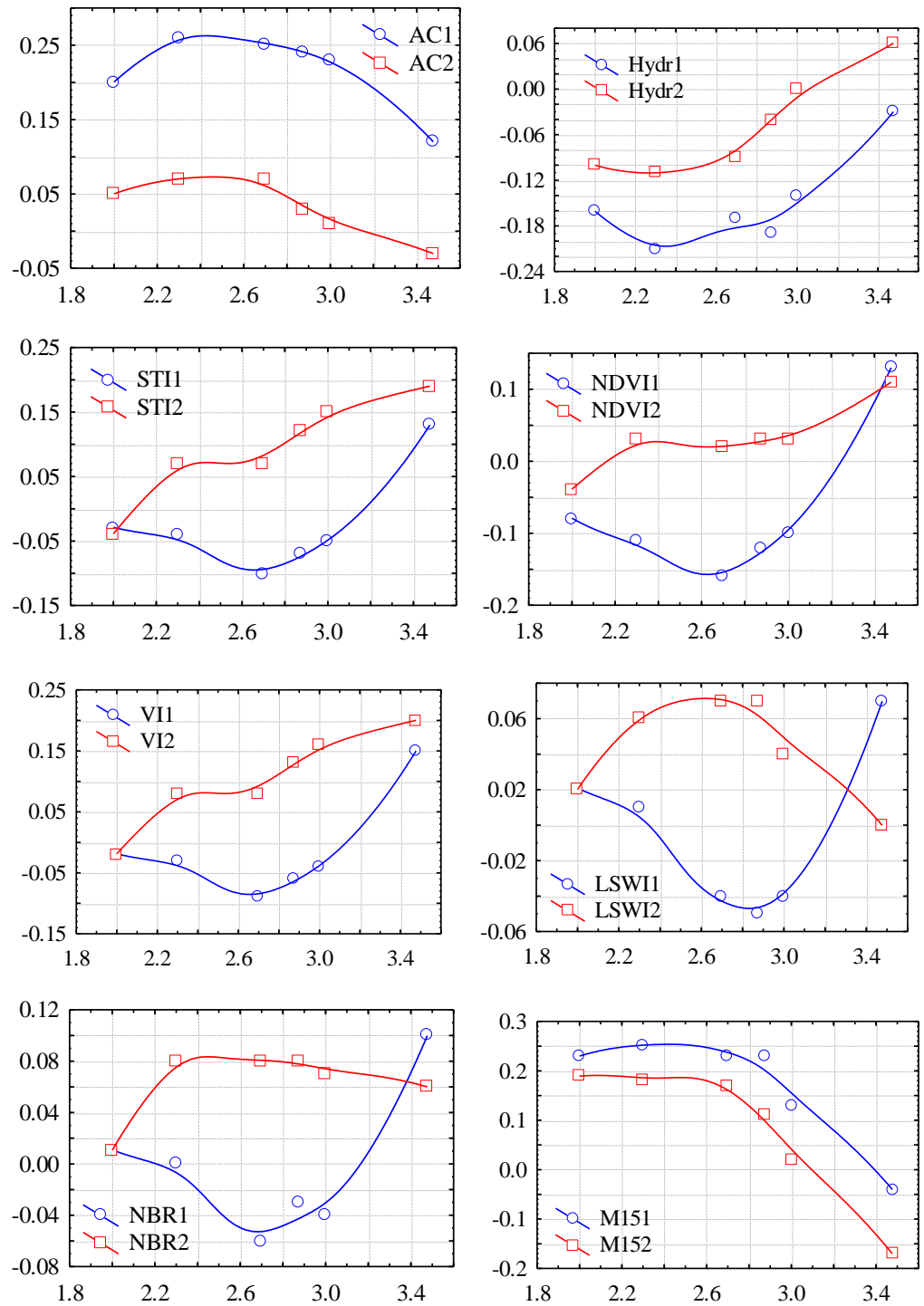

Fig. 14. Dependence of the marginality of ecogeographic variables (Landsat indices) on the scale of consideration (on the abscissa axis is the logarithm of the maximum distance of pseudo-absence from the location of mounds) 
At the same time, the sign of marginality changes from negative to positive. This suggests that in a landscape-wide context, mole rats prefer terrain areas with a high degree of slope steepness. But in places with high density of mounds, mole rats prefer more gentle microstations. The TPI index shows that, of all microstates, mole rats choose areas with negative values of this index (concave positions), while in the general landscape context they give preference to convex ones. Other geomorphological indices detail the results obtained. The main result is that, within the landscape as a whole, mole-rats prefer areas with preserved steppe vegetation. This type of biogeocenosis corresponds to the ecological optimum of this steppe species. The disturbance of the soil and vegetation cover during agricultural use made the habitat conditions of mole-rats on the plateau, where steppe complexes were located in the pre-agricultural period, unacceptable. Therefore, the mole rats were displaced to the stations where soil cover and natural steppe vegetation were still preserved. According to formal signs, such geomorphological markers as a decrease in relief level, increase in surface slope and curvature, degrees of terrain ruggedness and others associated with them, form optimal in these conditions of existence ecological regimes for mole-rats. However, the different-scale approach to ecological niche characterization indicates the ecological fidelity of mole-rats and their ecological conservatism. Other things being equal, mole-rats choose more gentle, more drained, and less rugged microhabitats.

In a number of cases, the polarity of microhabitat-landscape context does not exhaust the large-scale specificity of the ecological niche of mole-rats. Non-monotonic (with the presence of an extremum) changes in marginality are characteristic of a number of indicators. To the greatest extent, the presence of extremes is characteristic of vegetation indices. It is likely that the scale of extremum manifestation coincides with the dimensional boundaries of biogeocenoses, which are determined by phytocenosis. The ecological plasticity of plants smoothes the variability of soil and relief conditions, which determines the possibility of manifestation of more complex effects in the configuration of the ecological niche of mole rats. 

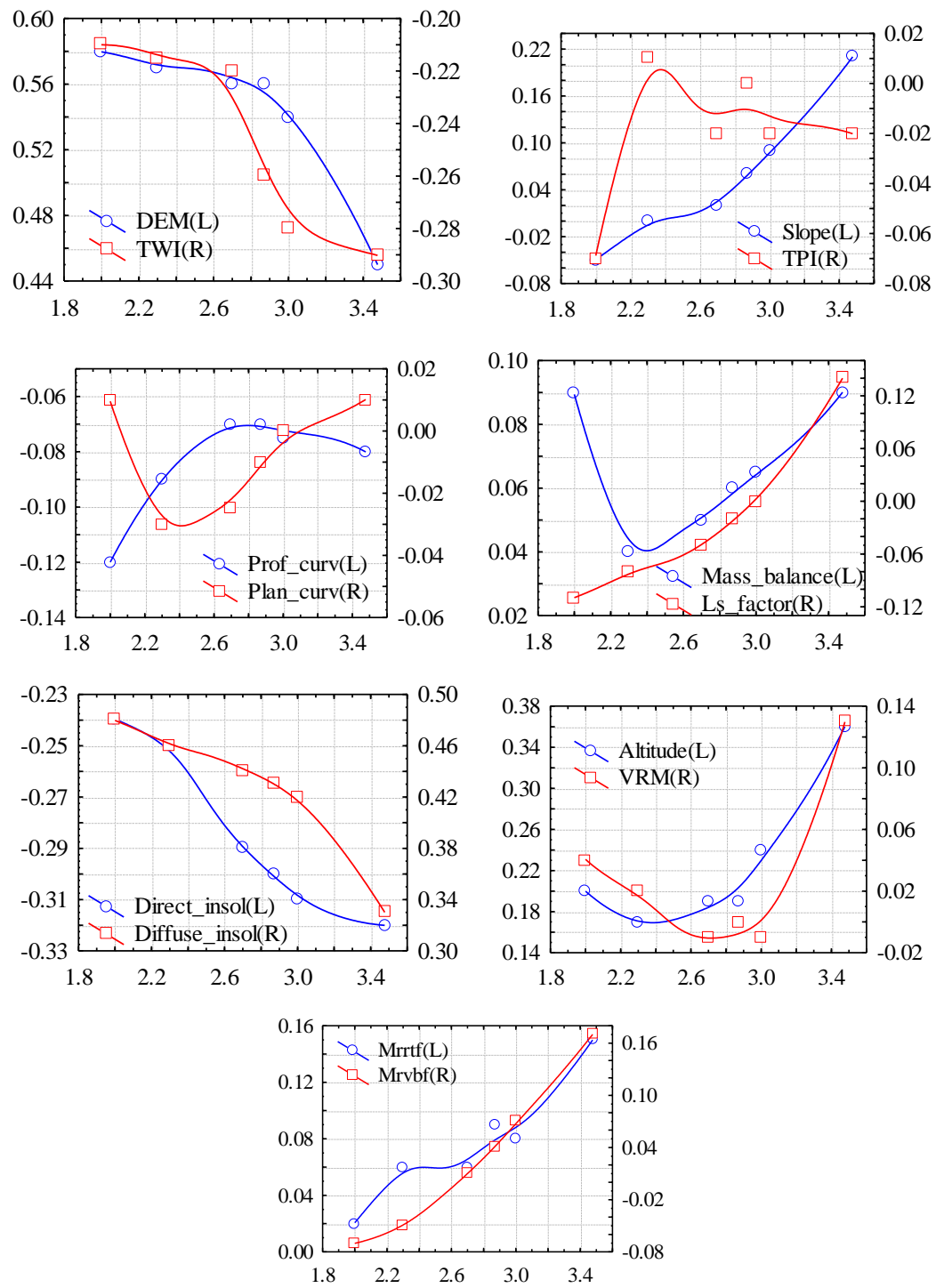

Fig. 15. Dependence of the marginality of ecogeographic variables (geomorphological indicators) on the scale of observation (on the abscissa axis is the logarithm of the maximum distance of pseudo-absence points from the location of mounds) 


\section{CONCLUSIONS}

The habitat suitability index is a continuum model of the ecological space of a species, which was obtained on the basis of point counts, information on the spatial variation of possible ecogeographic variables, and the factor structure model of the animal's ecological niche. It is shown that ecogeographic variables derived from remote sensing data of the Earth's surface (relief indices and vegetation cover characteristics) are suitable for effective description of the spatial distribution of mole-rats.

2. The marginal niche of mole rats according to ENFA analysis is related to topography. Mole rat mounds are most likely to be found on steep, concave slopes. The marginality of the ecological niche of mole rats is most strongly determined by the VRM index (vector measure of terrain roughness), erosion factor, surface slope the tillage index (clay mineral index) and the vegetation index. Together, these indices clearly mark eroded elements of relief with remnants of natural steppe vegetation.

3. An important feature of the ecological niche of the mole rat, identified by the ENFA analysis, is the fact that the geomorphological characteristics do not determine the specialization of the niche of a given animal. The key markers of the specialization axis are vegetation indices (NDVI, NBR, M15). These features emphasize the importance of spring vegetation dynamics in determining the configuration of the ecological niche of mole rats. The high pedoturbation activity of these animals should be supported by sufficient trophic resources supplied by actively vegetating plants. The favorable conditions are characterized by biogeocenoses which are included in the ravine and gully system with remnants of natural steppe vegetation and undisturbed soil cover.

\section{SUMMARY}

The global climate change is a significant challenge of our time. This circumstance makes it difficult to predict the state of animal populations and communities for the purpose of their conservation and rational exploitation. The main idea of the study is to take into account the role of vegetation and topography to identify the trends of animal changes under the influence of climate change. The results of the study can be used in the implementation of projects to assess the impact of technological projects on the environment.

\section{References}

1. Бельгард А.Л. Лесная растительность Юго-Востока УССР. Киев : Изд-во КГУ, 1950. 263 с. 
2. Арнольди К.В., Арнольди Л.В. О биоценозе как одном из основных понятий экологии, его структуре и объеме. Зоологический журнал. 1963. Vol. 42, No. 2. C. 161-183.

3. Чернов Ю.И. Природная зональность и животный мир суши: Москва : Мысль, 1975. 222 с.

4. Кирпотин С.Н. Жизненные формы организмов как паттерны организации и пространственные экологические факторы. Журнал общ. биологии. 2005. Vol. 66, No. 3. C. 239-250.

5. Pavlinov, I. Comments on biomorphics (ecomorphological) systematics. Zhurnal obshchei biologii. 2010. Vol. 71, No. 2. P. 187-92.

6. Кашкаров Д.Н. Основы экологии животных. М.-Л.: Медгиз, 1938. $602 \mathrm{c}$.

7. Алеев Ю.Г. Экоморфология. Киев : Наукова думка, 1986. 424 с.

8. Zhukov, A.V., Kunah, O.N., Prokopenko, E.V. The pedoturbation activity of the mole rats (Spalax microphthalmus) as a factor og the spatial organization of the spider (Aranei). News of Dnipropetrovsk State Agrarian and Economic University. 2011. Vol. 6. P. 28-35.

9. Andrusevich, K.V., Zhukov, A.V., Kunah, O.N. Ecomorphic organisation of the mesopedobionts community as the basis of the anthropogenic soils zoological diagnostic. The Journal of V.N. Karazin Kharkiv National University. Biology. 2014. Vol. 1126, No. 22. P. 89-97.

10.Zhukov, O., Kunah, O., Dubinina, Y., та ін. The role of edaphic and vegetation factors in structuring beta diversity of the soil macrofauna community of the Dnipro river arena terrace. Ekológia (Bratislava). 2018. Vol. 37, No. 3. P. 301-327.

11. Findik, Ö. Spatial and seasonal distribution of macroinvertebrates in high altitude reservoir (Beyler Reservoir, Turkey). Chinese Journal of Oceanology and Limnology. 2013. Vol. 31, No. 5. P. 994-1001.

12. Gongalsky, K. B., Belorustseva, S. A., Kuznetsova, D. М., та ін. Spatial avoidance of patches of polluted chernozem soils by soil invertebrates. Insect Science. 2009. Vol. 16, No. 1. P. 99-105.

13. Maslikova, K.P., Zhukov, O.V. Біологічне різноманіття та екосистемні сервіси техноземів, створених на територіях видобутку корисних копалин. Agrology. 2019. Vol. 2, No. 4. Р. 247-257.

14.Жуков О.В. Екоморфічний аналіз консорцій грунтових тварин: Дніпропетровськ : Вид-во «Свідлер А. Л.», 2009. 239с.

15.Покаржевский А.Д., Гонгальский К.Б., Зайцев А.С., та ін. Пространственная экология почвенных животных: Москва : Товарищество научных изданий КМК, 2007. 174 с.

16. Bookstein, F.L. Tensor biometrics for changes in cranial shape. Annals of Human Biology. 1984. Vol. 11, No. 5. P. 413-437. 
17.Principal, T., Analysis, T., Leibovici, A.D., та ін. Package 'PTAk .' 2012.

18. Kunah, O.N. Functional and spatial structure of the urbotechnozem mesopedobiont community. Visnyk of Dnipropetrovsk University. Biology, ecology. 2016. Vol. 24, No. 2. P. 473-483.

19.Zhukov, A.V., Kunah, O.N., Novikova, V.A., та ін. Phytoindication estimation of soil mesopedobionts communities catena and their ecomorphic organization. Biological Bulletin of Bogdan Chmelnitskiy Melitopol State Pedagogical University. 2016. Vol. 6, No. 3. P. 91-117.

20.Zhukov, O., Kunah, O., Dubinina, Y., та ін. The role of edaphic, vegetational and spatial factors in structuring soil animal communities in a floodplain forest of the Dnipro river. Folia Oecologica. 2018. Vol. 45. P. 8-23.

21.Криволуцкий Д.А. Жизненные формы и биологическое разнообразие животных. Бюллетень Московского общества испьтателей природы. Отд. Биол. 1999. Vol. 104, No. 5. С. 61-67.

22.Gams, H. Prinzipienenfragen der Vegetationsforschung. Ein Beitrag zur Bergiffsklarung und Methodik der Biocoenologie. Vierteljahrsschr. Naturf. Ges. Zurich. 1918. Vol. 63. P. 293-493.

23. Friederichs, K. Die Grundfragen und Gesetzmassigkeiten der land- und forstwirschaftlichen Zoologie, insbesondere der Entomologie: Berlin: Parey, 1930. Bd. 1. - 417 S.; Bd. 2-463 S.c.

24. Акимов М.П. Биоценотическая рабочая схема жизненных форм - биоморф. Науч. зап. Днепропетр. Гос. ун-та. 1948. С. 61-64.

25.Бельгард А.Л. Степное лесоведение: Москва : Лесная промышленность, $1971.336 \mathrm{c.}$

26.Zhukov A.V. Интерпретация ценоморф растений юго-востока Украины в терминах фитоиндикационных шкал. Acta Biologica Sibirica. 2018. Vol. 4, No. 4. P. 57-70.

27.Zhukov, A.V., Kunah, O.N., Novikova, V.A. та ін. Фитоиндикационное оценивание катены сообществ почвенной мезофауны и их экоморфическая организация. Biological Bulletin of Bogdan Chmelnitskiy Melitopol State Pedagogical University. 2016. Vol. 6, No. 3. P. 91-117.

28.Zhukov, A.V., Shatalin, D.B. Гигротоп и трофотоп биогеоценозов степного приднепровья как детерминанты $\beta$-разнообразия сообществ дождевых червей (Lumbricidae). Biological Bulletin of Bogdan Chmelnitskiy Melitopol State Pedagogical University. 2016. Vol. 6, No. 2. P. 188-222. 
29.Brind'Amour, A., Daniel, B., Dray, S., та ін. Relationships between species feeding traits and environmental conditions in fish communities: A three-matrix approach. Ecological Applications. 2011. Vol. 21, No. 2. P. 363-377.

30. Olden, J.D., Jackson, D.A. A comparison of statistical approaches for modelling fish species distributions. Freshwater Biology. 2002. Vol. 47, No. 10. P. 1976-1995.

31.Dornelas, M., Magurran, A.E., Buckland, S.T., та ін. Quantifying temporal change in biodiversity: challenges and opportunities. Proceedings of the Royal Society B: Biological Sciences. 2013. Vol. 280, No. 1750.

32.Davies, T.J., Regetz, J., Wolkovich, E. M., та ін. Phylogenetically weighted regression: A method for modelling non-stationarity on evolutionary trees. Global Ecology and Biogeography. 2019. Vol. 28, No. 2. P. 275-285.

33.McGill, B.J., Etienne, R.S., Gray, J.S., та ін. Species abundance distributions: Moving beyond single prediction theories to integration within an ecological framework. Ecology Letters. 2007. Vol. 10, No. 10. P. 995-1015.

34.McGill, B.J., Enquist, B.J., Weiher, E., та ін. Rebuilding community ecology from functional traits. Trends in Ecology and Evolution. 2006. Vol. 21, No. 4. P. 178-185.

35.Austen, D.J., Bayley, P.B., Menzel, B.W. Importance of the Guild Concept to Fisheries Research and Management. Fisheries. 1994. Vol. 19, No. 6. P. 12-20.

36.Hardy, O.J., Jost, L. Interpreting and estimating measures of community phylogenetic structuring. Journal of Ecology. 2008. Vol. 96, No. 5. P. 849-852.

37. Mouillot, D., Spatharis, S., Reizopoulou, S., та ін. Alternatives to taxonomic-based approaches to assess changes in transitional water communities. Aquatic Conservation: Marine and Freshwater Ecosystems. 2006. Vol. 16, No. 5. P. 469-482.

38. Brind'Amour, A., Mahévas, S., Legendre, P., та ін. Application of Moran Eigenvector Maps (MEM) to irregular sampling designs. Spatial Statistics. 2018. Vol. 26. P. 56-68.

39. Lososová, Z., Šmarda, P., Chytrý, M., та ін. Phylogenetic structure of plant species pools reflects habitat age on the geological time scale. Journal of Vegetation Science. 2015. Vol. 26, No. 6. P. 1080-1089.

40. Billeter, R., Liira, J., Bailey, D., та ін. Indicators for biodiversity in agricultural landscapes: A pan-European study. Journal of Applied Ecology. 2008. Vol. 45, No. 1. P. 141-150. 
41.Zobel, M. The relative role of species pools in determining plant species richness: An alternative explanation of species coexistence? / Elsevier Ltd, 1997. p. 266-269.

42. Angermeier, P. L., Winston, M. R. Local vs. Regional Influences on Local Diversity in Stream Fish Communities of Virginia. Ecology. 1998. Vol. 79, No. 3. P. 911.

43. Vergnes, A., Blouin, M., Muratet, A., та ін. Initial conditions during Technosol implementation shape earthworms and ants diversity. Landscape and Urban Planning. 2017. Vol. 159. P. 32-41.

44. Tóth, Z., Szlavecz, K., Epp Schmidt, D. J., та ін. Earthworm assemblages in urban habitats across biogeographical regions. Applied Soil Ecology. 2020. Vol. 151.

45. Roithmeier, O., Pieper, S. Influence of Enchytraeidae (Enchytraeus albidus) and compaction on nutrient mobilization in an urban soil. Pedobiologia. 2009. Vol. 53, No. 1. P. 29-40.

46. Tóth, Z., Hornung, E. Taxonomic and functional response of Millipedes (Diplopoda) to urban soil disturbance in a metropolitan area. Insects. 2019. Vol. 11, No. 1. P. 25.

47. Martynenko, I.A., Meshalkina, J.L., Rappoport, A.V. Spatial heterogeneity of some soil properties of the botanical garden of Lomonosov Moscow State University: Springer Geography. Springer, 2019.

48.Gan, H., Wickings, K. Soil ecological responses to pest management in golf turf vary with management intensity, pesticide identity, and application program. Agriculture, Ecosystems and Environment. 2017. Vol. 246. P. 66-77.

49. Goncharova, O.Y., Matyshak, G.V., Udovenko, M.M., Seasonal and annual variations in soil respiration of the artificial landscapes (Moscow Botanical Garden): Springer Geography. Springer, 2019.

50. Smorkalov, I.A., Vorobeichik, E.L. The impact of a large industrial city on the soil respiration in forest ecosystems. Eurasian Soil Science. 2015. Vol. 48, No. 1. P. 106-114.

51. Vorobeichik, E.L. Populations of earthworms (Lumbricidae) in forests of the middle urals in conditions of pollution by discharge from copper works. Russian Journal of Ecology. 1998. Vol. 29, No. 2. C. $85-91$.

52. Vorobeichik, E.L., Ermakov, A.I., Zolotarev, M.P., та ін. Changes in diversity of soil macrofauna in industrial pollution gradient. Rej. 2012. Vol. 21, No. 1. P. 203-218.

53. Medvedev, V. V. Soil penetration resistance and penetrographs in studies of tillage technologies. Eurasian Soil Science. 2009. Vol. 42, No. 3. P. 299-309. 
54.Демидов А.А., Кобец А.С., Грицан Ю.И. та ін. Пространственная агроэкология и рекультивация земель. Днепропетровск : «Свидлер А.Л.», 2013. 560 с.

55.Huang, Y., Yang, X., Zhang, D., та ін. The effects of gap size and litter species on colonization of soil fauna during litter decomposition in Pinus massoniana plantations. Applied Soil Ecology. 2020. Vol. 155.

56. Tresch, S., Frey, D., Bayon, R. C. Le, тa iн. Litter decomposition driven by soil fauna, plant diversity and soil management in urban gardens. Science of the Total Environment. 2019. Vol. 658. P. 1614-1629.

57.Buisson, L., Thuiller, W., Lek, S., та ін. Climate change hastens the turnover of stream fish assemblages. Global Change Biology. 2008. Vol. 14, No. 10. P. 2232-2248.

58. Thuiller, W., Lavorel, S., Midgley, G., та ін. Relating plant traits and species distributions along bioclimatic gradients for 88 Leucadendron taxa. Ecology. 2004. Vol. 85, No. 6. P. 1688-1699.

59.Santoul, F., Cayrou, J., Mastrorillo, S., та ін. Spatial patterns of the biological traits of freshwater fish communities in south-west France. Journal of Fish Biology. 2005. Vol. 66, No. 2. P. 301-314.

60.Dolédec, S., Chessel, D., Braak, C.J.F. Ter, та ін. Matching species traits to environmental variables: A new three-table ordination method. Environmental and Ecological Statistics. 1996. Vol. 3, No. 2. C. $143-166$.

61.Dray, S., Saïd, S., Débias, F. Spatial ordination of vegetation data using a generalization of Wartenberg's multivariate spatial correlation. Journal of Vegetation Science. 2008. Vol. 19, No. 1. P. 45-56.

62. Minden, V., Andratschke, S., Spalke, J., та ін. Plant traitenvironment relationships in salt marshes: Deviations from predictions by ecological concepts. Perspectives in Plant Ecology, Evolution and Systematics. 2012. Vol. 14, No. 3. P. 183-192.

63.Thuiller, W., Richardson, D. M., Rouget, M., та ін. Interactions between environment, species traits, and human uses describe patterns of plant invasions. Ecology. 2006. Vol. 87, No. 7. P. 1755-1769.

64.Bernhardt-Römermann, M., Römermann, C., Nuske, R., та ін. On the identification of the most suitable traits for plant functional trait analyses. Oikos. 2008. Vol. 117, No. 10. P. 1533-1541.

65. Minden, V., Andratschke, S., Spalke, J., та ін. Plant traitenvironment relationships in salt marshes: Deviations from predictions by ecological concepts. Perspectives in Plant Ecology, Evolution and Systematics. 2012. Vol. 14, No. 3. P. 183-192. 
66. Caliñski, T., Harabasz, J. A Dendrite Method Foe Cluster Analysis. Communications in Statistics. 1974. Vol. 3, No. 1. P. 1-27.

67.Hill, M.O. Correspondence Analysis: A Neglected Multivariate Method. Applied Statistics. 1974. Vol. 23, No. 3. P. 340.

68. Hill, M.O. Reciprocal Averaging: An Eigenvector Method of Ordination. The Journal of Ecology. 1973. Vol. 61, No. 1. P. 237.

69. Thioulouse, J., Simier, M., Chessel, D. Simultaneous analysis of a sequence of paired ecological tables. Ecology. 2004. Vol. 85, No. 1. P. 272-283.

70. Doledec, S., Chessel, D., Gimaret-Carpentier, C. Niche Separation in Community Analysis: A New Method. Ecology. 2000. Vol. 81, No. 10. P. 2914.

71.Braak, C.J.F. Ter, Barendregt, L. G. Weighted averaging of species indicator values: Its efficiency in environmental calibration. Mathematical Biosciences. 1986. Vol. 78, No. 1. P. 57-72.

72.Palmer, M.W. Putting Things in Even Better Order: The Advantages of Canonical Correspondence Analysis. Ecology. 1993. Vol. 74, No. 8. P. 2215-2230.

73. Boycott, A.E. The habitats of land mollusca in Britain. The Journal of Ecology. 1934. Vol. 22, No. 1. P. 1.

74. Cameron, R. Differences in the distributions of three species of helicid snail in the limestone district of Derbyshire. Proceedings of the Royal Society of London. Series B. Biological Sciences. 1970. Vol. 176, No. 1043. P. 131-159.

75. Baur, A., Baur, B. Individual movement patterns of the minute land snail Punctum pygmaeum (Draparnaud) (Pulmonata: Endodontidae). Veliger. 1988. Vol. 30. P. 372-376.

76. Kramarenko, S.S., Kunakh, O.N., Zhukov, A.V, та ін. Analysis of the spatial distribution patterns of the land snail populations: a geostatistic method approach. 2016. No. February. P. 5-40.

77.Huston, M. A General Hypothesis of Species Diversity. The American Naturalist. 1979. Vol. 113, No. 1. P. 81-101.

78. Pielou, E.C. An Introduction to Mathematical Ecology: New York: Wiley-Interscience, 1969. 294 p.

79. Southwood, T.R.E., Henderson, P.A. Ecological Methods, 3rd edn. Blackwell Science, 2000.

80. Fortin Dale, M.R.T., ver Hoef, J, M.-J. Spatial analyses in ecology. Encyclopedia of environmetrics. 2002. Vol. 4. P. 2051-2058.

81. Chambers, R., Trippel, E. Early life history and recruitment in fish populations / Chapman and Hall, 1997. 
82.Calenge, C., Dufour, A.B., Maillard, D. K-select analysis: A new method to analyse habitat selection in radio-tracking studies. Ecological Modelling. 2005. Vol. 186, No. 2. P. 143-153.

83.Doak, D.F., Bigger, D., Harding, E.K., та ін. The statistical inevitability of stability-diversity relationships in community ecology. American Naturalist. 1998. Vol. 151, No. 3. P. 264-276.

84. Tokeshi, M. Resource Utilization, Overlap and Temporal Community Dynamics: A Null Model Analysis of an Epiphytic Chironomid Community. The Journal of Animal Ecology. 1986. Vol. 55, No. 2. P. 491.

85.Green, J.L., Harte, J., Ostling, A. Species richness, endemism and abundance patterns: Tests of two fractal models in a serpentine grassland. Ecology Letters. 2003. Vol. 6, No. 10. P. 919-928.

86. Shipitalo, M.J., Bayon, R.C.Le. Quantifying the effects of earthworms on soil aggregation and porosity. Earthworm Ecology, Second Edition. 2004. P. 183-200.

87. Wootton, J.T. Field parameterization and experimental test of the neutral theory of biodiversity. Nature. 2005. Vol. 433, No. 7023. P. 309-312.

88. McGill, B.J. A test of the unified neutral theory of biodiversity. Nature. 2003. Vol. 422, No. 6934. P. 881-885.

89. Volkov, I., Banavar, J.R., Hubbell, S.P., та ін. Neutral theory and relative species abundance in ecology. Nature. 2003. Vol. 424, No. 6952. P. 1035-1037.

90. Adler, P.B., Lauenroth, W.K. The power of time: Spatiotemporal scaling of species diversity. Ecology Letters. 2003. Vol. 6, No. 8. P. 749-756.

91.Thompson, R., Townsend, C. A truce with neutral theory: Local deterministic factors, species traits and dispersal limitation together determine patterns of diversity in stream invertebrates. Journal of Animal Ecology. 2006. Vol. 75, No. 2. P. 476-484.

92.Zhou, S., Zhang, D. Neutral theory in community ecology. Frontiers of Biology in China. 2008. Vol. 3, No. 1. P. 1-8.

93.SP, H. The Unified Neutral Theory of Biodiversity and Biogeography / Princeton University Press, Princeton, NJ.

94. Karst, J., Gilbert, B., Lechowicz, M. J. Fern community assembly: the roles of chance and the environment at local and intermediate scales. Ecology. 2005. Vol. 86, No. 9. P. 2473-2486.

95. Townsend, C. R., Hildrew, A. G. Species traits in relation to a habitat templet for river systems. Freshwater Biology. 1994. Vol. 31, No. 3. C. $265-275$. 
96. Hutchinson, G. E. Concluding Remarks. Cold Spring Harbor Symposia on Quantitative Biology. 1957. Vol. 22, No. 0. P. 415-427.

97. Calenge, C., Basille, M. A general framework for the statistical exploration of the ecological niche. Journal of Theoretical Biology. 2008. Vol. 252, No. 4. P. 674-685.

98. Hirzel, A. H., Hausser, J., Chessel, D., та ін. Ecological-niche factor analysis: How to compute habitat-suitability maps without absence data? Ecology. 2002. Vol. 83, No. 7. P. 2027-2036.

99. Caruso, N., Guerisoli, M., Luengos Vidal, E. M., та ін. Modelling the ecological niche of an endangered population of Puma concolor: First application of the GNESFA method to an elusive carnivore. Ecological Modelling. 2015. Vol. 297. P. 11-19.

100. Angelo, C. De, Paviolo, A., Bitetti, M. Di. Differential impact of landscape transformation on pumas (Puma concolor) and jaguars (Panthera onca) in the Upper Paraná Atlantic Forest. Diversity and Distributions. 2011. Vol. 17, No. 3. P. 422-436.

101. Galparsoro, I., Borja, Á., Bald, J., та ін. Predicting suitable habitat for the European lobster (Homarus gammarus), on the Basque continental shelf (Bay of Biscay), using Ecological-Niche Factor Analysis. Ecological Modelling. 2009. Vol. 220, No. 4. P. 556-567.

102. Valle, M., Borja, A., Chust, G., та ін. Modelling suitable estuarine habitats for Zostera noltii, using Ecological Niche Factor Analysis and Bathymetric LiDAR. Estuarine, Coastal and Shelf Science. 2011. Vol. 94, No. 2. P. 144-154.

103. Halstead, B.J., Wylie, G.D., Casazza, M.L. Habitat Suitability and Conservation of the Giant Gartersnake (Thamnophis gigas) in the Sacramento Valley of California. Copeia. 2010. Vol. 2010, No. 4. P. 591-599.

104. Hemery, L., Galton-Fenzi, B., Améziane, N., та ін. Predicting habitat preferences for Anthometrina adriani (Echinodermata) on the East Antarctic continental shelf. Marine Ecology Progress Series. 2011. Vol. 441. P. 105-116.

105. Thiebot, J.-B., Lescroël, A., Pinaud, D., та ін. Larger foraging range but similar habitat selection in non-breeding versus breeding subAntarctic penguins. Antarctic Science. 2011. Vol. 23, No. 2. P. 117-126.

106. Stéphane, D. Moran's eigenvectors of spatial weighting matrices in R. 2006. Vol. 3. P. 1-21.

107. Gendreau-berthiaume, B. Lab 9 - Spatial analysis: Trend surface analysis and PCNM. Oecologia. 2004. P. 9.

108. Legendre, P., Fortin, M. J. Spatial pattern and ecological analysis. Vegetatio. 1989. Vol. 80, No. 2. P. 107-138. 
109. Borcard, D., Legendre, P. All-scale spatial analysis of ecological data by means of principal coordinates of neighbour matrices. Ecological Modelling. 2002. Vol. 153, No. 1-2. P. 51-68.

110. Fischer, M.M. Quantifying the uncertainty of variance partitioning estimates of ecological datasets. Environmental and Ecological Statistics. 2019. Vol. 26, No. 4. P. 351-366.

111. Leibold, M.A., Holyoak, M., Mouquet, N., та ін. The metacommunity concept: A framework for multi-scale community ecology. 2004. P. 601-613

112. Hutchinson, G.E. Ecological Aspects of Succession in Natural Populations. The American Naturalist. 1941. Vol. 75, No. 760. P. 406-418.

113. Gauch, H.G., Chase, G.B., Whittaker, R.H. Ordination of Vegetation Samples by Gaussian Species Distributions. Ecology. 1974. Vol. 55, No. 6. P. 1382-1390.

114. Chesson, P. General theory of competitive coexistence in spatially-varying environments. Theoretical Population Biology. 2000. Vol. 58, No. 3. P. 211-237.

115. Smith, T.W., Lundholm, J.T. Variation partitioning as a tool to distinguish between niche and neutral processes. Ecography. 2010. Vol. 33, No. 4. P. 648-655.

116. Houlahan, J.E., Currie, D.J., Cottenie, K., та ін. Compensatory dynamics are rare in natural ecological communities. Proceedings of the National Academy of Sciences of the United States of America. 2007. Vol. 104, No. 9. P. 3273-3277.

117. Saetre, P., Bååth, E. Spatial variation and patterns of soil microbial community structure in a mixed spruce-birch stand. Soil Biology and Biochemistry. 2000. Vol. 32, No. 7. P. 909-917.

118. Layeghifard, M., Makarenkov, V., Peres-Neto, P. R. Spatial and species compositional networks for inferring connectivity patterns in ecological communities. Global Ecology and Biogeography. 2015. Vol. 24, No. 6. P. 718-727.

119. Gilbert, B., Bennett, J. R. Partitioning variation in ecological communities: Do the numbers add up? Journal of Applied Ecology. 2010. Vol. 47, No. 5. P. 1071-1082.

120. Lichstein, J.W., Simons, T.R., Shriner, S.A., та ін. Spatial autocorrelation and autoregressive models in ecology. Ecological Monographs. 2002. Vol. 72, No. 3. P. 445-463.

121. Legendre, P., Borcard, D., Peres-Neto, P. R. Concep Ts \& Synthesis Emphasizing New Ideas To Stimulate Research in Ecology Analyzing Beta Diversity: Partitioning the Spatial Variation of 
Community Composition Data. Ecological Monographs. 2005. Vol. 75, No. 4. P. 435-450.

122. Blanchet, F.G., Legendre, P., Borcard, D. Modelling directional spatial processes in ecological data. Ecological Modelling. 2008. Vol. 215, No. 4. P. 325-336.

123. Santos, N.D., Gonçalves, G. Remote Sensing Applications Based on Satellite Open Data (Landsat8 and Sentinel-2). 2014. P. 1-10.

124. Kunah, O.M., Papka, O.S. Ecogeographical determinants of the ecological niche of the common milkweed (Asclepias syriaca) on the basis of indices of remote sensing of land images. Visnyk of Dnipropetrovsk University. Biology, ecology. 2016. Vol. 24, No. 1. P. 78-86.

125. Deventer, A.P. Van, Ward, A.D., Gowda, P.M., та ін. Using thematic mapper data to identify contrasting soil plains and tillage practices. Photogrammetric Engineering and Remote Sensing. 1997. Vol. 63, No. 1. C. 87-93.

126. Li, P., Jiang, L., Feng, Z. Cross-comparison of vegetation indices derived from landsat-7 enhanced thematic mapper plus (ETM+) and landsat-8 operational land imager (OLI) sensors. Remote Sensing. 2013. Vol. 6, No. 1. P. 310-329.

127. Bernardes, T., Gontijo, I., Andrade, H., та ін. Digital Terrain Models Derived from SRTM Data and Kriging: Innovations in 3D Geo Information Systems. 2006.

128. Marder, L., Corbellini, V. A., Ferrão, M. F., та ін. Quantitative analysis of total mycotoxins in metabolic extracts of four strains of Bipolaris sorokiniana (Helminthosporium sativum). Process Biochemistry. 2006. Vol. 41, No. 1. P. 177-180.

129. Beven, K. J., Kirkby, M. J. A physically based, variable contributing area model of basin hydrology. Hydrological Sciences Bulletin. 1979. Vol. 24, No. 1. P. 43-69.

130. I. D. Moore, J. P. W. Length-slope factors for the Revised Universal Soil Loss Equation: Simplified method of estimation. Journal of Soil and Water Conservation. 1992. Vol. 47. P. 423-428.

131. Guisan, A., Weiss, S. B., Weiss, A. D. GLM versus CCA spatial modeling of plant species distribution. Plant Ecology. 1999. Vol. 143, No. 1. P. 107-122.

132. Möller, M., Volk, M., Friedrich, K., та ін. Placing soil-genesis and transport processes into a landscape context: A multiscale terrainanalysis approach. Journal of Plant Nutrition and Soil Science. 2008. Vol. 171, No. 3. P. 419-430. 
133. Wischmeier, W.H., Smith, D.D. Predicting rainfall erosion loss: A guide to conservation planning. Agricultural Handbook No. 537 / US Department of Agriculture-Agricultural Research Service, 1978.

134. Renard, K.G., Meyer, L.D., Foster, G.R. Revised Soil Universal Soil Loss Equation. 1997. C. 1-18.

135. Böhner, J., Antonić, O. Chapter 8 Land-Surface Parameters Specific to Topo-Climatology: Geomorphometry: Concepts, software, applications. 2009.

136. Orlanski, J. A rational subdivision of scales for atmospheric processes. Bulletin of the American Meteorological Society. 1975. Vol. 56. C. 527-530.

137. Potapenko, O., Kunah, O. M., Fedushko, M. P. The effect of technological oil spill in soil within electrical generation substations, analysed by ecological regime in the context of relief properties. Biosystems Diversity. 2019. Vol. 27, No. 1. C. 43-50.

138. Eisank, C., Smith, M., Hillier, J. Assessment of multiresolution segmentation for delimiting drumlins in digital elevation models. Geomorphology. 2014. Vol. 214. C. 452-464.

139. Gallant, J. C., Dowling, T.I. A multiresolution index of valley bottom flatness for mapping depositional areas. Water Resources Research. 2003. Vol. 39, No. 12.

140. Sappington, J.M., Longshore, K.M., Thompson, D.B. Quantifying Landscape Ruggedness for Animal Habitat Analysis: A Case Study Using Bighorn Sheep in the Mojave Desert. Journal of Wildlife Management. 2007. Vol. 71, No. 5. P. 1419-1426.

\section{Information about the authors: Kunakh Olga Mykolaivna,}

Doctor of Biological Sciences, Professor, Professor at the Department of Zoology and Ecology

Oles Honchar Dnipro National University 72, Gagarin avenue, Dnipro, 49000, Ukraine

Zhukov Olexander Viktorovich, Doctor of Biological Sciences, Professor, Professor at the Department of Botany and Horticulture Bogdan Khmelnitsky Melitopol State Pedagogical University 20, Hetmanska str., Melitopol, Zaporizhzhia region, 72318, Ukraine 